\title{
Review: Nanofibers for Biomedical and Healthcare
}

\section{Applications}

\author{
Rahimeh Rasouli ${ }^{*}$, Ahmed Barhoum ${ }^{2 *}$, Mikhael \\ Bechelany $^{3}$, Alain Dufresne ${ }^{4}$
}

${ }^{1}$ Department of Medical Nanotechnology, International Campus, Tehran University of Medical Sciences, Tehran, Iran.

${ }^{2}$ Department of Materials and Chemistry, Faculty of Engineering, Vrije Universiteit Brussel (VUB), Pleinlaan 2, 1050 Brussels, Belgium

${ }^{3}$ Institut Européen des Membranes, IEM - UMR 5635, ENSCM, CNRS, Univ Montpellier, Montpellier, France

${ }^{4}$ LGP2, Grenoble INP, CNRS, Université Grenoble Alpes, Grenoble, France

Email: $\underline{\text { r-rasouli@ razi.tums.ac.ir, ahmed.abdelrasoul@vub.ac.be, }}$

ahmed.barhoum@science.helwan.edu.eg

\begin{abstract}
Unique features of nanofibers provide enormous potential in the field of biomedical and healthcare applications. Many studies have proven the extreme potential of nanofibers in front of current challenges in the medical and healthcare field. This review highlights the history and development of nanofiber technologies, unique properties, fabrication techniques, and emerging applications in biomedical and healthcare fields. The review summarizes the recent researches on nanofibers for drug delivery system and controlled drug release, tissue-engineered scaffolds, dressings for wound healing, biosensors, biomedical devices, medical implants, cosmetics as well as removal of toxic particulate matter/ions from air, water, and blood. Attention is given to different types of fibers (e.g. mesoporous, hollow, core-shell nanofibers) fabricated from various materials and their potential biomedical applications.
\end{abstract}


Keywords: Nanofiber, Biomedical, Tissue engineering, Drug delivery, Biosensor, Cosmetics, Protective textiles, Medical filtration

\section{Introduction}

Nanofibers as one of the interested group of nanomaterials with two similar external dimensions in the nanoscale $(\leq 100 \mathrm{~nm})$ and the third dimension significantly larger. Nanofibers provide a lot of wonderful features such as the large surface area to volume ratio, possibility in surface functionalities, tunable porosity, a wide range of materials selection, and superior mechanical performance. ${ }^{13,14}$ These remarkable properties make the nanofibers an ideal candidate for a wide range of biomedical applications including tissue-engineered scaffolds (e.g. skin, cartilage, bone, blood vessel), ${ }^{15,16}$ dressings for wound healing, ${ }^{17,18}$ biomedical devices, ${ }^{19}$ biosensors, ${ }^{20,21}$ and drug delivery system. ${ }^{22,23}$

Nanofibers afford great flexibility in selecting biodegradable or non-degradable materials to give amazing properties such as finer control over drug release kinetics for drug delivery applications.

There is a possibility to immobilize enzymes, antimicrobial peptides, antibiotics, and growth hormones to nanofibers, or loading into the core of nanofibers. ${ }^{32-36}$ Nanofibrous mats provide a structure similar to native extracellular matrix with high interconnected porosity $(60-90 \%),{ }^{37}$ great absorbances, balanced moisture, and gas permeability bring an appropriate environment to protect the wound from exogenous infection. In addition, the ability of loading antimicrobials agents and drugs into nanofibers provides a great potential in the development of effective antimicrobial systems able to treat infections in the wound regions, prohibition of bacterial biofilm formation, prolonging drug release and decreasing the time of wound healing process. ${ }^{38-40}$

One of the main and interesting biomedical application areas of nanofibers is tissue engineering. Nowadays, tissue-engineered scaffolds considered as a satisfactory solution to help the health and quality of life for millions of patients worldwide with end-stage organ failure or tissue loss. Nanofiber scaffolds provide many appropriate properties such as high porosity, large surface area, 
biodegradability, mechanical properties, and biocompatibility to a cell which need for tissue regeneration and sustained release of drug or growth factors. ${ }^{41}$ Nanofibers have been used in wound dressing to promote the wound healing, hemostasis, skin regeneration, and treatment of diabetic ulcers (x). Nanofibers hold the moisture within their pores and keep the wound surface wet during the healing process. This prevents nanofiber sticking to the wound surface and accelerates the wound healing. Moreover, the oxygen can travel more easily between wound and dressing (x). Nanofiber membrane may be incorporated into wearable blood purification systems for the removal of toxins from the blood of kidney failure patients (x). Biosensors based on nanofibers show great promise for future applications in health-care testing and disease diagnostics. ${ }^{42}$ Nanofibers are a natural fit for gas masks and protective textiles, as their pore size is desired to provide adequate protection from aerosolized threats $(\mathrm{x})$.

Nanofibers provide 3D architecture with the desired surface properties regarding the intended application within the body in addition to mechanical strength and physiological acceptability. The present review summarizes history and development of nanofiber fabrication techniques, unique properties and applications of nanofiber in the biomedical and healthcare fields including tissueengineered scaffolds, dressings for wound healing, biomedical devices, implants, drug delivery system and controlled drug release.

\section{Nanofiber fabrication techniques}

Nanofiber fabrication techniques are varied and utilize mechanical, chemical, thermal, and electrostatic fabrication techniques. Various bottom-up and top-down approaches were proposed to produce nanofibers. Nanofiber fabrication techniques which can be generally classified into two main classifications: (i) physical, chemical, and biological techniques; and (ii) spinning and non-spinning fabrication techniques. In the next sections, these categories will be discussed in more details.

\subsection{Physical, Chemical, and Biological Techniques}


Nanofiber fabrication techniques can be classified into physical, chemical, and biological techniques based on the forces and actions applied to produce nanofibers. Physical methods apply high energy radiations, mechanical pressure, electrical energy or thermal energy to cause material melting, abrasion, evaporation or condensation to form nanofibers. Most common examples of physical fabrication techniques are mechanical milling,(x) physical vapor deposition,(x) laser ablation,(x) and spinning fabrication techniques. Ball milling, cryo-crushing, or high-pressure homogenization are commonly used top-down techniques to produce cellulose nanofibers from natural sources e.g. wood pulp.(x) Physical vapor deposition techniques such as Arc deposition,(x) plasma sputtering, $(\mathrm{x})$ thermal evaporation, $(\mathrm{x})$ and pulsed laser deposition, $(\mathrm{x})$ have been used to prepare metal oxide nanofibers and carbon nanofibers.

Chemical methods involve chemical reactions between two or more reacting species to form nanofibers. Such a chemical reaction can occur by simultaneously or be caused by an outside force such as high energy radiations, electrical energy or thermal energy to form nanofibers. Chemical vapor deposition (CVD),(x) electrochemical deposition, $(\mathrm{x})$ polyol synthesis, $(\mathrm{x})$ phase-separation, $(\mathrm{x})$ microemulsion,(x) sol-gel method,(x) hydrothermal synthesis(x) are some of the most commonly used chemical methods for the nanofiber synthesis. Ultrasound irradiation and microwave have been recently employed for wet chemistry synthesis of nanofibers. (x) Soft templates such as surfactant and polymers or hard porous templates such as polycarbonate membranes (PCM) (x) and anodic aluminum oxide (AAO) membranes $(\mathrm{x})$ are often used in combination with the chemical methods to produce nanofibers.

Biological methods involve biological reactions between nanofiber raw materials and bioactive species such as bacteria, enzymes in presence or absence of outside force such as mechanical pressure, high energy radiations, electrical energy or thermal energy. In case of biological treatments, cellulosic materials are treated with cellulolytic enzymes like cellulase that cleave the fiber structures to simpler ones (x). Bacterial cellulose (BC), produced by aerobic bacteria received ample of attention due to its unique physiochemical properties compared to plant cellulose (x). 


\subsection{Spinning and Non-Spinning Fabrication Techniques}

Typically, most of the physical and chemical fabrication techniques listed above section are nonspinning techniques. Spinning techniques employ outside forces such as electric force, centrifugal force, or compressed gas to draw threads of polymer solutions or polymer melts up to fiber diameters range from few nanometers to several micrometers. (x) Nanofiber spinning has been a process of great scientific and industrial interest due to its versatility, cost-efficiency and potential to be used in a wide range of applications, resulting in an outstanding potential for nanotechnology research. Nanofiber spinning techniques can be further classified into two major categories:

\section{(i) Electrospinning technique}

Electrospinning is a method based on the use of electrostatic forces for producing continuous fibers with the diameter range from several microns to few nanometers. In a typical electrospinning process, a polymer solution is placed into a syringe and then pushed to the tip of the syringe by external pumping applied by mechanical pistons. When the solution droplet is formed at the metallic needle, an electric voltage bias is applied between the metallic needle and a collector placed in front of it.(x) As the applied voltage is gradually increased, the electric forces overcome surface tension and a jet is produced and finally, the droplet elongates Taylor cone, from which polymer nanofibers are produced and then deposited on the collector. The jet is accelerated and stretched through the atmosphere with the evaporation of the solvent and is used for preparing interconnected mats of nanofibers on the oppositely charged grounded collector.

Bubble electrospinning,(x) melt electrospinning,(x) coaxial electrospinning,(x) self-bundling electrospinning, $(\mathrm{x})$ nanospider electrospinning(x) are most common electrospinning techniques. The fiber diameter, morphology, alignment, as well as molecular orientation are affected by the nature of collectors, applied voltage, distance between nozzle and collector, and dispersion flow rate.(x) Some researchers have reported on needleless electrospinning systems using rotating disks, rollers, balls, and bubbles to obtain huge amounts of nanofibers.(x) Among of several nanofiber processing 
techniques, co-electrospinning, side by side electrospinning, multi-jet electrospinning, co-axial electrospinning, emulsion electrospinning recognized as the easiest and effective methods for drug delivery and biomedical application.(x)

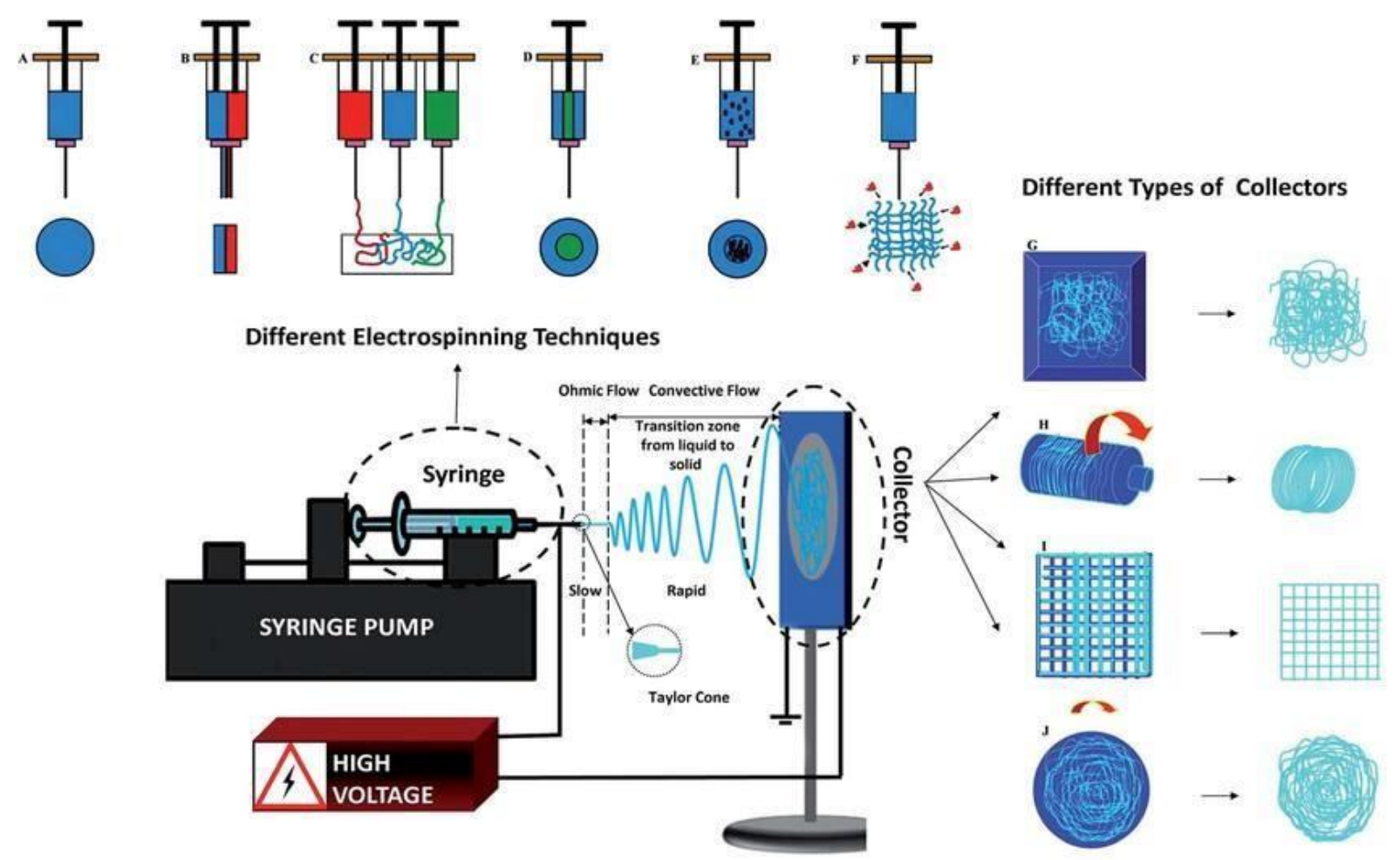

Figure 1. Schematic representation of different electrospinning techniques and types of collectors used for electrospinning. (A) Co-electrospinning; (B) side by side electrospinning; (C) multi-jet electrospinning; (D) co-axial electrospinning; (E) emulsion electrospinning; (F) electrospinning with surface immobilization; $(\mathrm{G})$ static plate; $(\mathrm{H})$ rotating mandrel; (I) grid; (J) rotating disk (x). Copyright 2016, Royal Society of Chemistry.

Aside from the electrospinning techniques and type of collectors, there are several factors affect the fiber diameter and morphology: (i) electrospinning parameters, for example applied electric field, distance between the needle and collector, flow rate, and needle diameter; (ii) solution parameters, for example solvent, polymer concentration, viscosity and solution conductivity; (iii) environmental parameters, for example relative humidity and temperature. Figure 2 shows the different morphologies of the electrospun nanofibers prepared at different electrospinning conditions. 

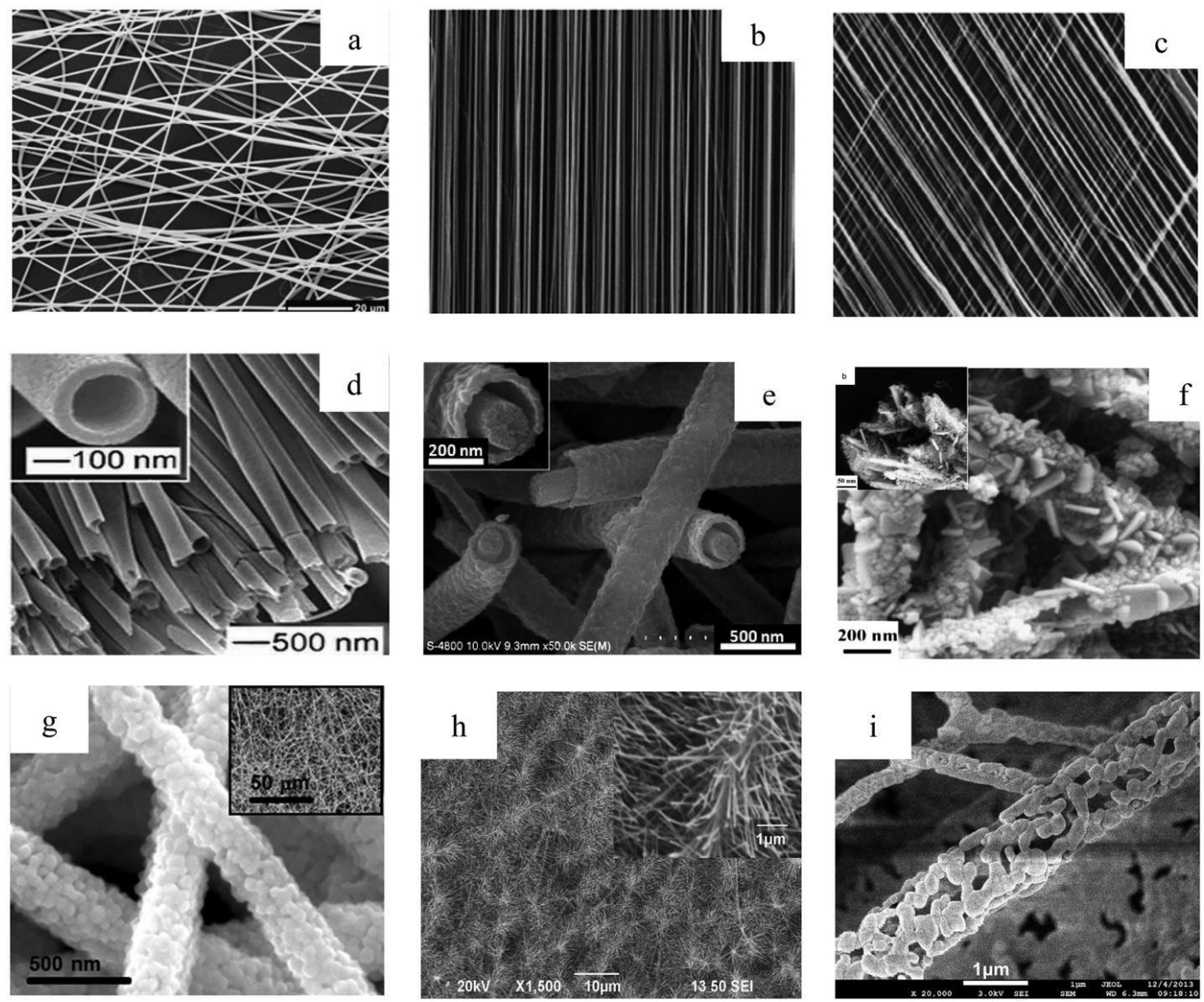

Figure 2. The different morphologies of the electrospun nanofibers: (a) randomly distributed nanofibers;

(b) aligned nanofibers; (c) patterned nanofibers; (d) hollow nanofibers; (e) core-shell nanofibers, (f) hybrid nanofibers; (g) functionalized composite nanofibers; (h) pine-needle-like nanofibers; (i) hollowed-out nanofibers. Copyright 2016, Royal Society of Chemistry (x).

\section{(ii) Non-electrospinning technique}

Non-electrospinning techniques use centrifugal force or compressed gases instead of an electric field to generate nanofibers. These techniques decrease the use of a solvent, increase the productivity, and lower the production cost. Blowing bubble spinning (gas-jet spinning),(x) centrifugal spinning, $(\mathrm{x})$ and fiber drawing(x) are three of the most common non-electrospinning nanofiber production techniques. As a high-output nanoscale fiber production method, centrifugal spinning can guarantee high fiber production rates, but it cannot produce high-performance fibers. 
The fibers produced by centrifugal spinning cannot be used in the high-precision terminal industry and biomedical fields because of the erratic performance of the fibers, which may cause irreversible side effects (x). Blown Bubble spinning uses blowing air or mechanical force to overcome the surface tension and produce nanofibers.

\section{Nanofibers for Tissue-Engineered Scaffolds}

There are millions of patients who suffer from end-stage organ failure or tissue loss around the world annually. ${ }^{43}$ Autologous and allogeneic natural tissue is generally used for replacement. Patency rates for these procedures are not $100 \%$, about $50-70 \%$ generally for coronary artery replacement, ${ }^{44}$ these surgeries cost billions of dollars in worldwide annually. ${ }^{45}$ The low number of donors is another limitation in front of transplantation. Nowadays, to address these problems tissue engineering brings a good alternative way to transplantation of diseased, failed, or abnormal organ or tissue. ${ }^{46}$ Tissue engineering scaffold provides a 3D environment for cell adhesion, proliferation and the specific arrangement of cells into complex tissue depends on the functional architecture of the organ. Three key elements are required for tissue engineering; scaffold, cells (differentiated or undifferentiated), and biological signaling molecules such as growth factors (GFs). ${ }^{47}$ Various processing techniques (e.g. phase separation, self-assembly, solvent casting, freeze drying, gas foaming, and electrospinning) have been employed to fabricate nanofiber scaffolds (Figure 3). Among them, the electrospinning as a straightforward and cost-effective process has attracted significant attention. Electrospun nanofiber can be fabricated from a wide range of materials with high similarity to the native extracellular matrix in different sizes and functions. ${ }^{48}$ Electrospun scaffolds have been employed in a number of different tissue applications including: vasculature, ${ }^{49-52}$ skin,${ }^{53,54}$ bone,${ }^{55-59}$ cartilage, ${ }^{60,61}$ neural, ${ }^{62,63}$ and tendon/ligament (Table 1). ${ }^{64-66}$ 
(a) Phase Separation

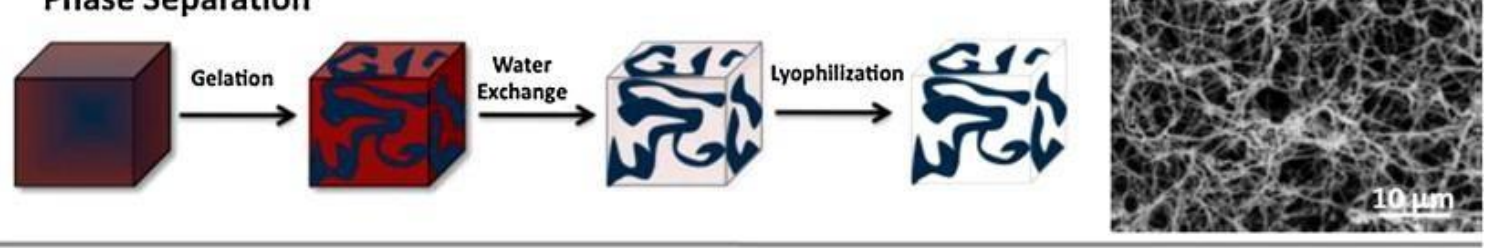

(b) Self-Assembly

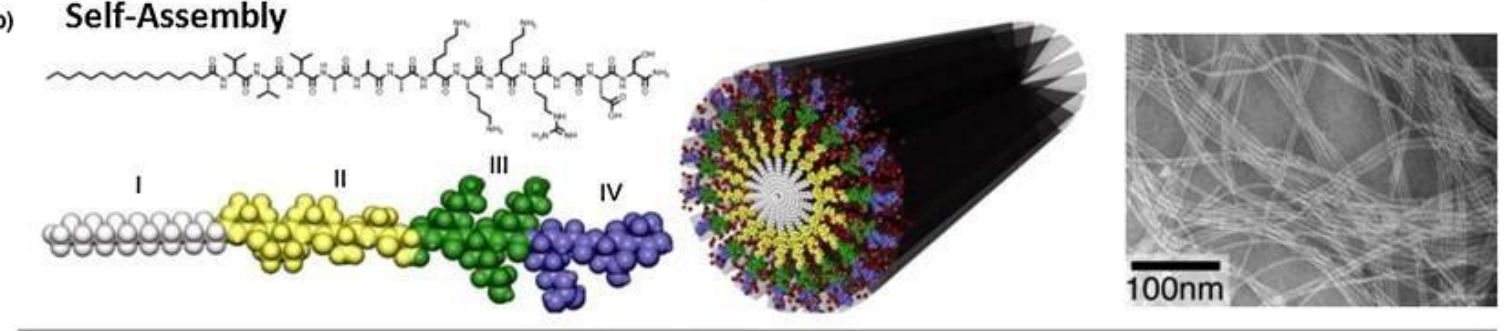

(c) Electrospinning

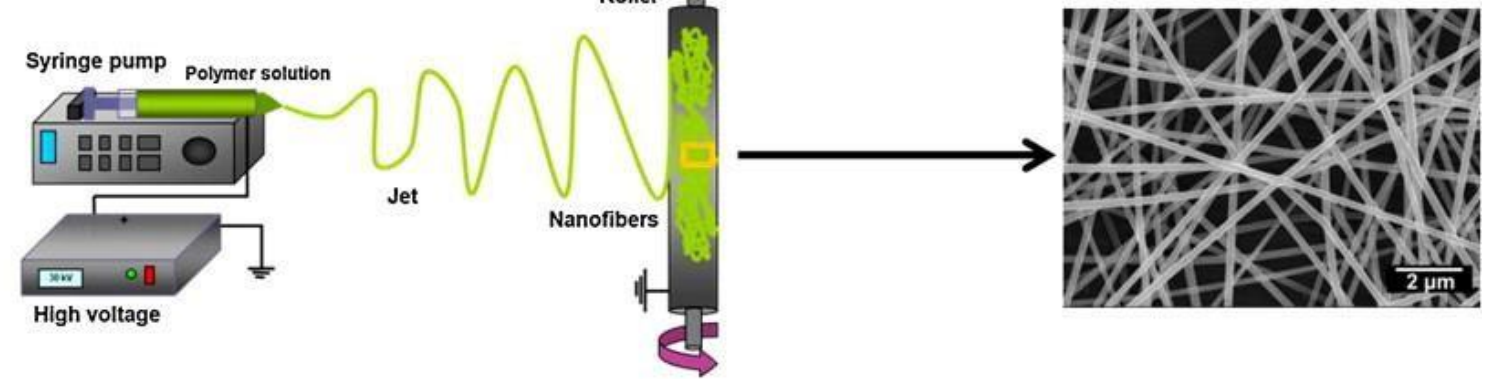

Figure 3. Schematic of some fabricating techniques such as phase separation (a), self-assembly (b) and electrospinning (c) to fabricate nanofibril structures in synthetic scaffolds. ${ }^{48}$ Copyright 2013, Elsevier.

Scaffolds with 3D structure can be synthesized of natural polymers, synthetic polymers or blends of synthetic and natural polymers. Chitin, chitosan, alginate, collagen, and gelatin are the most commonly used in nanofiber scaffolds. Synthetic polymers, such as polyglycolic acid, polylactic acid, polycaprolactone, poly(N-isopropyl acrylamide), and their copolymers have been also used for fabrication of scaffold (Table 1 and 2).$^{52,55,60,67-73}$ If necessary, the nanofibers can be further modified via adding bioactive agent (e.g. DNAs, enzymes, and growth factors) either incorporated via encapsulation or covalently conjugated to the matrix polymer to better control the proliferation and differentiation of cells seeded on the scaffolds. ${ }^{74}$ Wang et al. ${ }^{75}$ evaluated the efficacy of aligned electrospun chitosan fibrous tube as a protentional platform for enhancing peripheral nerve regeneration or for the treatment of demyelinating lesions using a Schwann cell-seeded to repair a 10-mm sciatic nerve defect. Figure 4 shows Schwann cells cultured on both random and oriented 
electrospun chitosan nanofiber coverslips. Aligned electrospun fibers enhanced Schwann cell maturation more than randomly oriented fibers. As a result, such aligned electrospun scaffolds may be an ideal platform for this purpose. ${ }^{75}$
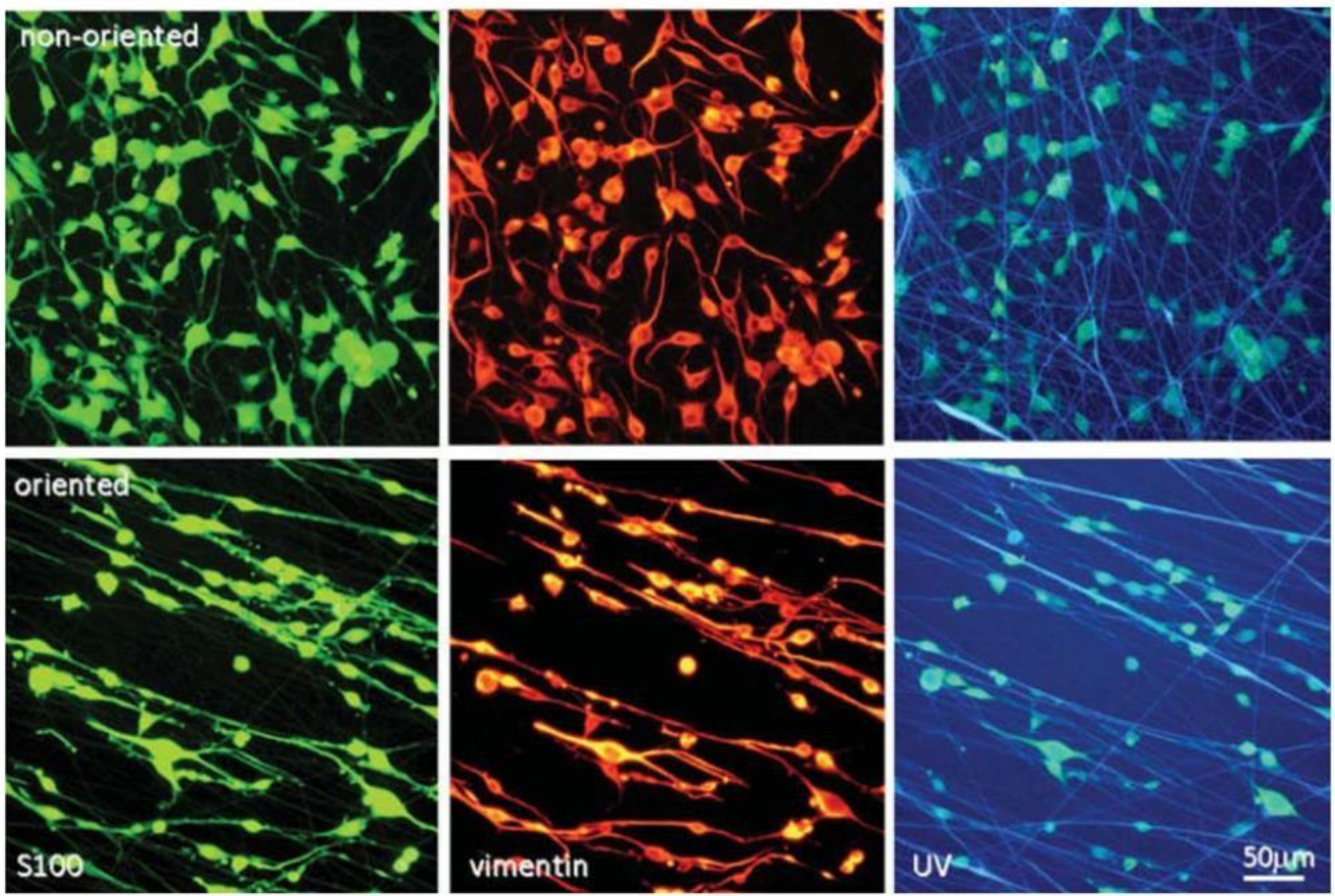

Figure 4. Schwann cell line growth on both random and oriented electrospun chitosan nanofiber coverslips for 4 days. $^{75}$ Copyright 2007, Elsevier.

Table 1. A number of different tissues fabricated out of synthetic polymers, natural polymers or blends of natural or synthetic polymers.

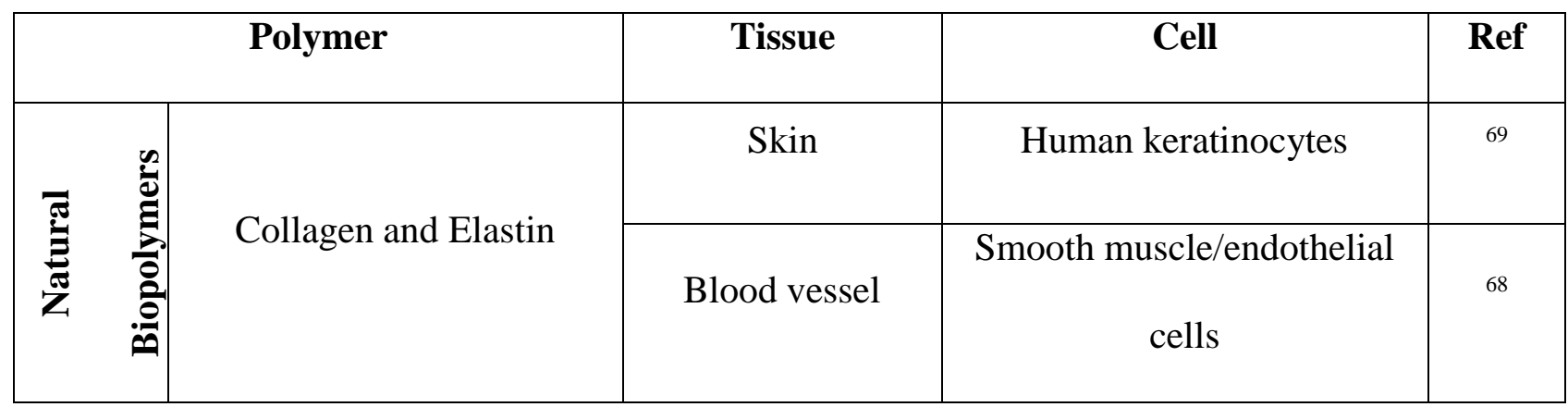




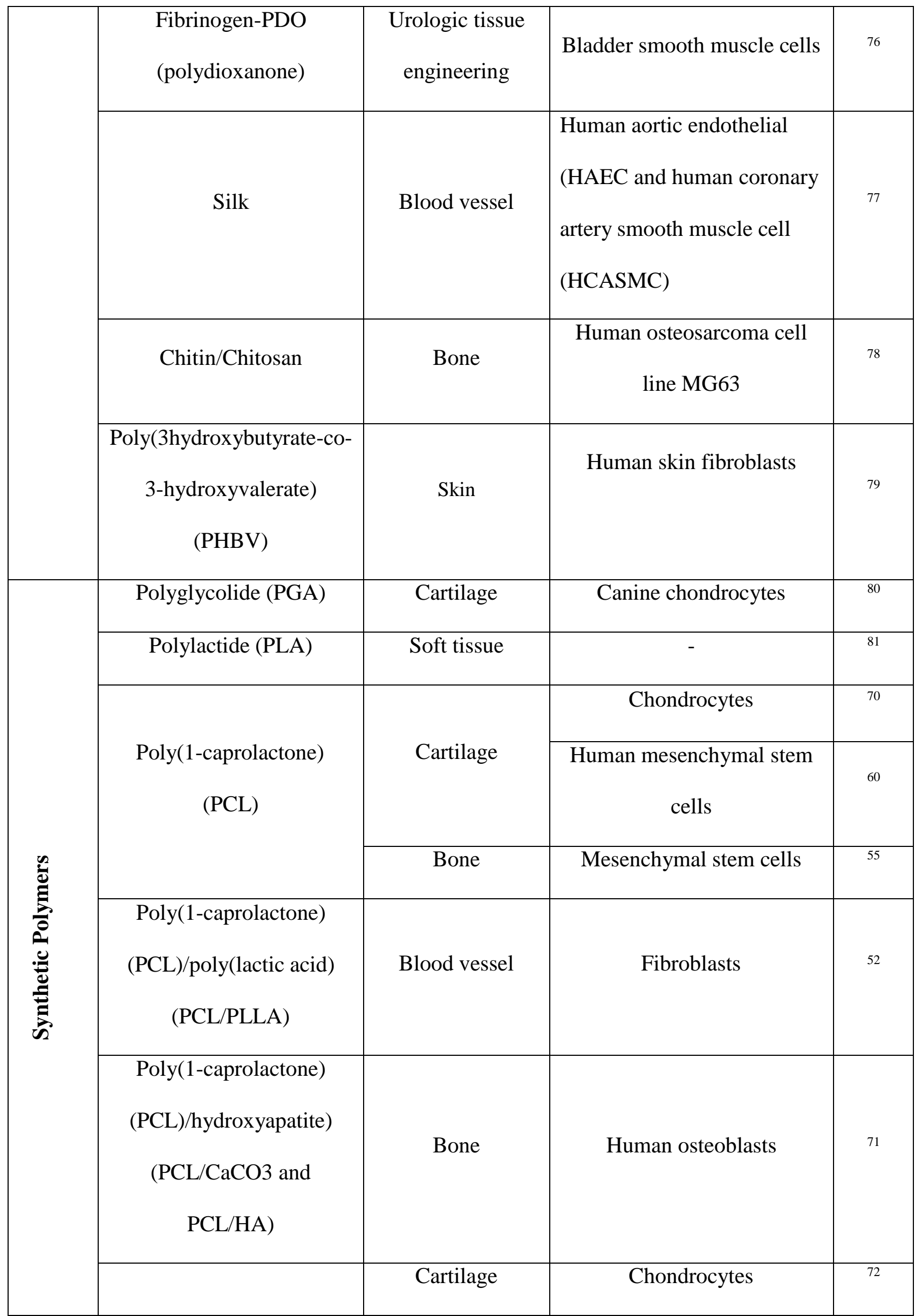




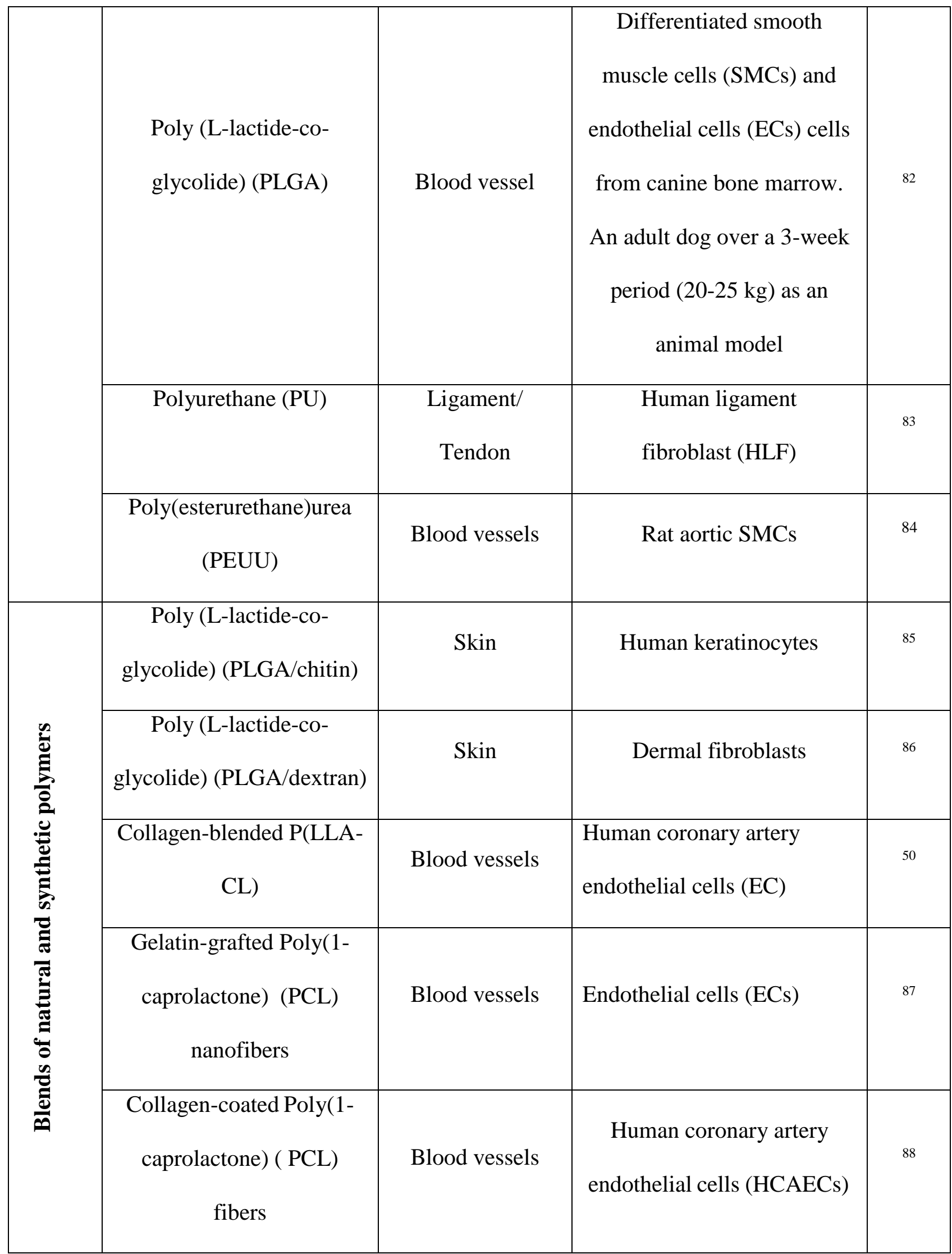

The structure and biological function of the scaffold must be similar to the native extracellular matrix.${ }^{89}$ Biodegradability, biocompatibility, nontoxicity, nonmutagenicity, and nonimmunogenicity 
are necessary properties for an appropriate scaffold. Surface properties (e.g. surface energy, chemistry, charge, surface area) should be able to promote cell adhesion, proliferation, and differentiation. ${ }^{89}$ Other important and essential physicochemical parameters of scaffolds should meet to develop a useful scaffold are external geometry (e.g., macro-, microstructure, interconnectivity), mechanical properties (e.g., compressive and tensile strength), porosity and size of pores ${ }^{90}$. Various structural parameters such as fiber diameter, porosity the ratio, spatial distribution and alignment of nanofibers, have critical impacts on the mechanical properties of scaffolds. For example, Ju et al. ${ }^{91}$ fabricated PCL/collagen bilayer scaffold with desired mechanical property by controlling nanofiber diameter. Enhanced the scaffold's porosity and reduced its Young's modulus from $4562.03 \mathrm{MPa}$ to $0.26 \mathrm{MPa}$ were resulted by increasing the fiber diameter from $0.27 \mu \mathrm{m}$ to $4.45 \mu \mathrm{m}$. The large pores on the outer layer of this fabricated poly $\varepsilon$-caprolactone (PCL)/collagen bilayer scaffold promoted SMC infiltration and small pore on an inner layer facilitated EC attachment (Figure 5). ${ }^{92}$
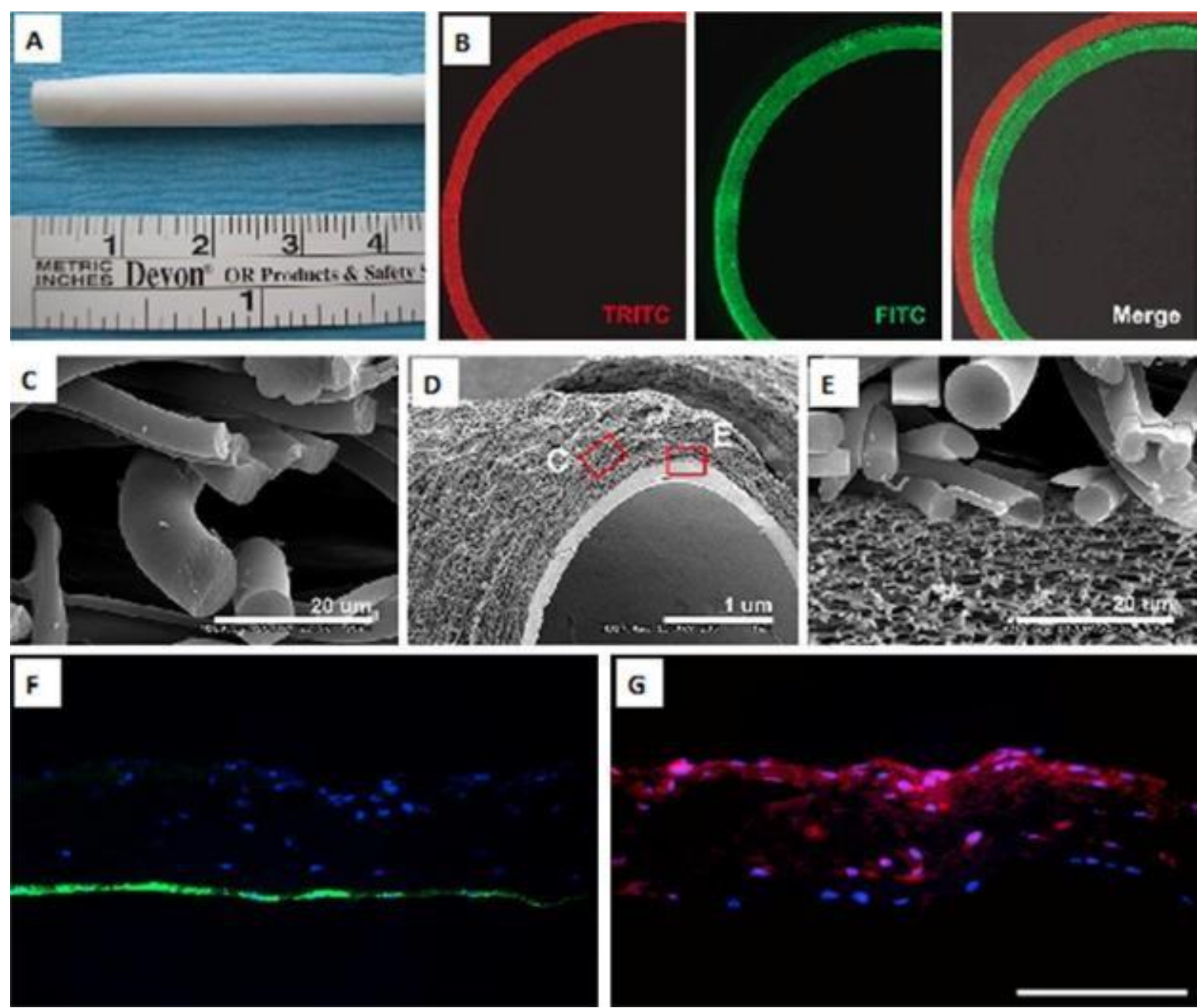
Figure 5. Electrospun Scaffolds for Tissue Engineering of Vascular Grafts: (A,B) Macrostructure and fluorescent images of PCL/collagen bilayer electrospun scaffold; (C-E) SEM images of different layers of the scaffold outer layer, bilayer and interface layers, $(\mathrm{F}-\mathrm{G})$ fluorescent images of poly $\varepsilon^{-}$ caprolactone (PCL), and smooth muscle cell (SMC) seeded scaffold: fluorescent images of endothelial cell (EC) seeded inner layer (the formation of an monolayer of endothelial cell (ECs) confirmed via CD31 expression :green) (F), and fluorescent images of SMC seeded outer layer (SMC infiltration into the outer layer demonstrated by a-SMA expression: red) (G). (scale bar in F and G: $500 \mathrm{~lm}) .{ }^{91}$ Copyright 2014, Elsevier.

Table 2. A number of different tissue applications of nanofibrous scaffolds.

\begin{tabular}{|c|c|c|c|}
\hline Application & Nanofiber Materials & Cell/Signal & Ref \\
\hline \multirow{4}{*}{ Blood Vessels } & $\begin{array}{l}\text { A bi-layered tubular scaffold of an } \\
\text { oriented and stiff polylactide (PLA) } \\
\text { outside fibrous layer and a randomly } \\
\text { oriented and pliable poly( } \varepsilon \text {-caprolactone) } \\
\text { (PCL) fibrous as an inner layer }\end{array}$ & $\begin{array}{l}3 \mathrm{~T} 3 \text { mouse fibroblasts } \\
\text { and human venous } \\
\text { myofibroblasts (HVS) }\end{array}$ & 52 \\
\hline & $\begin{array}{l}\text { Aligned poly(1-lactide-co- } \varepsilon^{-} \\
\text {caprolactone) }[\mathrm{P}(\mathrm{LLA}-\mathrm{CL})](75: 25)\end{array}$ & $\begin{array}{c}\text { Human coronary } \\
\text { artery smooth muscle } \\
\text { cells (SMCs) }\end{array}$ & 49 \\
\hline & $\begin{array}{l}\text { Poly (methacrylic acid) (PMAA)- } \\
\text { polyethylene terephthalate (PET) } \\
\text { nanofiber mats were modified with } \\
\text { gelatin. }\end{array}$ & $\begin{array}{l}\text { Endothelial cells } \\
\qquad \text { (ECs) }\end{array}$ & 51 \\
\hline & $\begin{array}{l}\text { Poly( } \varepsilon \text {-caprolactone) (PCL)/gelatin } \\
\text { blend }\end{array}$ & $\begin{array}{l}\text { Human mesenchymal } \\
\text { stem cells (hMSCs) }\end{array}$ & 93 \\
\hline
\end{tabular}




\begin{tabular}{|c|c|c|c|}
\hline & Polyurethane (PU) & $\begin{array}{l}\text { Endothelial progenitor } \\
\text { cell (EPC) }\end{array}$ & 94 \\
\hline \multirow{5}{*}{ Bone } & $\begin{array}{l}\text { Microporous, non-woven poly }(\varepsilon- \\
\text { caprolactone) }(\mathrm{PCL})\end{array}$ & $\begin{array}{l}\text { Mesenchymal stem } \\
\text { cells (MSCs) derived } \\
\text { from the bone marrow } \\
\text { of neonatal rats }\end{array}$ & 55 \\
\hline & $\begin{array}{l}\text { Silk fibroin fiber scaffolds containing } \\
\text { bone morphogenetic protein and/or } \\
\text { hydroxyapatite nanoparticles }\end{array}$ & $\begin{array}{l}\text { Human bone marrow- } \\
\text { derived mesenchymal } \\
\text { stem cells (hMSCs) }\end{array}$ & 56 \\
\hline & Poly( $\varepsilon$-caprolactone) (PCL) & $\begin{array}{l}\text { MSCs derived from } \\
\text { the bone marrow of } \\
\text { neonatal rats }\end{array}$ & 57 \\
\hline & Hydroxyapatite/chitosan (HAp/CTS) & $\begin{array}{l}\text { Human fetal } \\
\text { osteoblast (hFOB) } \\
\text { cells }\end{array}$ & 95 \\
\hline & $\begin{array}{l}\text { Blend of polycaprolactone (PCL), } \\
\text { hydroxyapatite (HA), and natural } \\
\text { polymer gelatin (Gel) }\end{array}$ & $\begin{array}{l}\text { Human fetal } \\
\text { osteoblast (hFOB) } \\
\text { cells }\end{array}$ & 96 \\
\hline \multirow{3}{*}{ Heart } & $\begin{array}{l}\text { Nonwoven poly(lactide) and } \\
\text { poly(glycolide)-based (PLGA) }\end{array}$ & $\begin{array}{c}\text { Primary } \\
\text { cardiomyocytes } \\
\text { (CMs) }\end{array}$ & \\
\hline & $\begin{array}{l}\text { Polyacrylonitrile (PAN)/ Hydrogel Com } \\
\text { Posite }\end{array}$ & $\begin{array}{l}\text { Normal human aortic } \\
\text { valve interstitial cells } \\
\text { (nHAVIC) }\end{array}$ & 97 \\
\hline & $\begin{array}{c}\text { Hyperbranched poly-L-lysine } \\
\text { dendrimers (HPLys)/ polyaniline }\end{array}$ & Cardiomyocyte & 98 \\
\hline
\end{tabular}




\begin{tabular}{|c|c|c|c|}
\hline & $\begin{array}{l}\text { Copolymer poly(l-lactic acid)-co-poly } \\
\text { (E-caprolactone) (PLACL), silk fibroin } \\
(\mathrm{SF}) / \text { Aloe Vera (AV) }\end{array}$ & Cardiac cell & 99 \\
\hline & Poly (L-lactide-co-glycolide) (PLGA) & Cardiomyocyte & 100 \\
\hline & Polyurethane (PU)/Ethyl cellulose (EC) & $\begin{array}{c}\text { Cardiac myoblast } \\
\text { H9C2 cells }\end{array}$ & 101 \\
\hline & $\begin{array}{l}\text { Poly(lactic-co-glycolic acid)/ } \\
\text { Multiwalled carbon nanotube } \\
\text { (MWCNTs) }\end{array}$ & Cardiomyocyte & 102 \\
\hline \multirow{5}{*}{ Cartilage } & $\begin{array}{l}\text { Poly(vinyl alcohol)/polycaprolactone } \\
\qquad(\mathrm{PVA} / \mathrm{PCL})\end{array}$ & $\begin{array}{l}\text { Rabbit bone marrow- } \\
\text { mesenchymal stem } \\
\text { cell (BM-MSC) }\end{array}$ & 103 \\
\hline & Lactic acid/glycolic acid & chondrocyte & 72 \\
\hline & Polycaprolactone (PCL) & $\begin{array}{l}\text { Human mesenchymal } \\
\text { stem cells (hMSCs) }\end{array}$ & 104 \\
\hline & Poly( $\varepsilon$-caprolactone) (PCL) & $\begin{array}{l}\text { Adult bone marrow } \\
\text { derived mesenchymal } \\
\text { stem cells (MSCs) }\end{array}$ & 60 \\
\hline & $\begin{array}{l}\text { Poly(lactic acid) (PLLA) nanofibers } \\
\text { (NF) were modified with cationized } \\
\text { gelatin (CG) }\end{array}$ & Condrocyte & 61 \\
\hline Skin & $\begin{array}{l}\text { Poly( } \varepsilon \text {-caprolactone) (PCL) nanofibres } \\
\text { with bioactive glass NPs }\end{array}$ & $\begin{array}{c}\text { Human } \\
\text { skin fibroblast cells } \\
\text { (HSFs) }\end{array}$ & 105 \\
\hline
\end{tabular}




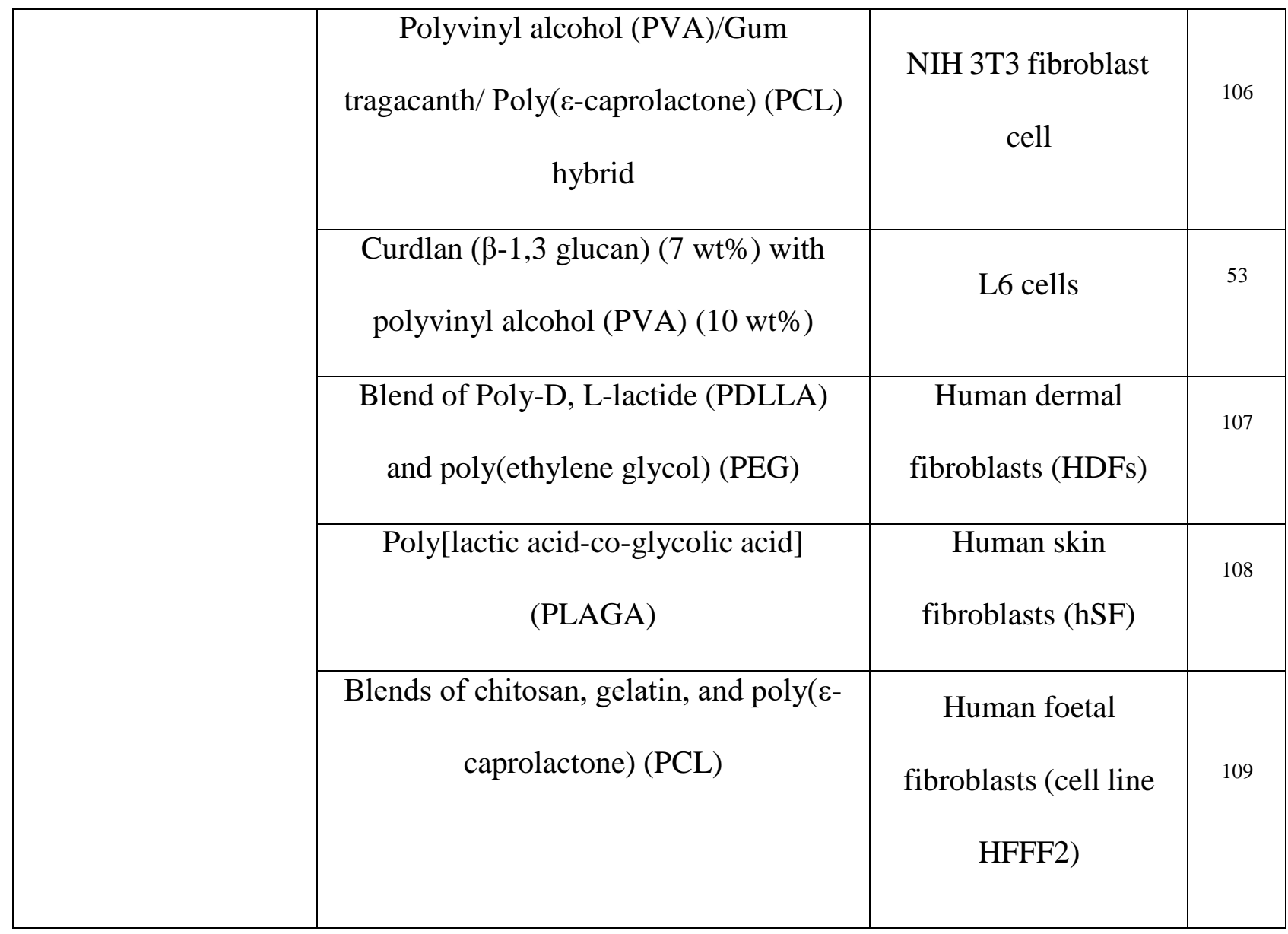

\section{Biosensors and health monitoring system}

Nanofiber technology has opened a new promising window in design and fabrication of the miniaturized dimensions biosensors with high surface to volume for immobilization and sensing, cause to enhance the catalytic properties of electrodes, exceptional ability to boost the desirable sensitivity, specificity and accelerate the reaction rate. Among of various types of nanostructured materials, the nanofibers-based biosensor has potential to develop towards even single-molecule biosensing. Retaining the bioreceptor functionality is one of the main challenges associated with the production of nanofiber-based biosensors. To obtain highly sensitive biosensors, the nanofiber mats should provide a large active surface area to ensure that the bioreceptor does not only keep their biological functionality but also remain accessible to the molecules to be detected. To retain the biological functionality of the biosensors, the receptors can be immobilized using various strategies, to optimize the physical and chemical interactions between the nanofibers and bioreceptors. Surface 
immobilization has been typically used to immobilize enzymes, antibodies, DNA strands, and aptamers on nanofiber surface. Another approach is loading the bioactive molecules inside the nanofiber by electrospinning a blend of enzymes and polymer (x).

Generally, nanofiber-based biosensors reveal great potential for applications in disease diagnostics and health-care testing. Nanofibers have been employed to detect a wide range of analytes including glucose,${ }^{20}$ urea, ${ }^{110}$ cholesterol, ${ }^{111}$ and nucleic acids.(x) They have been fabricated a various range of material according to their application. ${ }^{12}$ Nanofibers with high porosity and interconnectivity have been proved good diffusion of analytes, faster electron transfer in comparison with a film made of NPs with the same material, excellent mechanical properties and high bioactivity of immobilized materials. ${ }^{113-116}$ Interest nanofiber-based biosensors in DNA detection has grown rapidly due to in diagnosis and treatment of genetic disease, viral or bacterial pathogens and combat with bioterrorism threats and drug discovery. ${ }^{117}$

Recently, nanofiber-based biosensors as a miniature, portable, sensitive and accurate point-ofcare diagnostic devices have been employed for detection of genetic disorders and specific viral or bacterial pathogens. The main reason of much genetic disorder is a mismatch in a single base pair, diagnosis of this mismatch is able with this kind of biosensor. In the development of these biosensors have been taken the benefit of the specific affinity of DNA or PNA (peptide nucleic acid) for hybridization with its complementary strand. ${ }^{118}$ By these devices, some success has been reported pathogenic microbe detection such as Escherichia coliO157:H7 ${ }^{119} 120$ and bovine viral diarrhea virus (BVDV) ${ }^{119}$ malarial parasites, ${ }^{121}$ Hepatitis B virus. ${ }^{122}$ Luo et al. used the electrospinning method to fabricate electrospun capture membrane made of nitrocellulose nanofibrous and its antibody functionalization (Figure 6A). ${ }^{119}$ Electrospun based biosensor on the capture membrane is designed by capillary immunoassay, direct-charge electrical measurement and integrating magnetic separation, for rapid and quantitative detection of viral and bacterial pathogens (Figure 6B). A pair of electrodes was constructed on the capture membrane via a spray deposition of Ag paint. The biosensor was 
fabricated by attaching the three membrane pads onto polyvinylidene chloride (PVDC) substrate using polystyrene adhesive backing (Figure 7). ${ }^{119}$
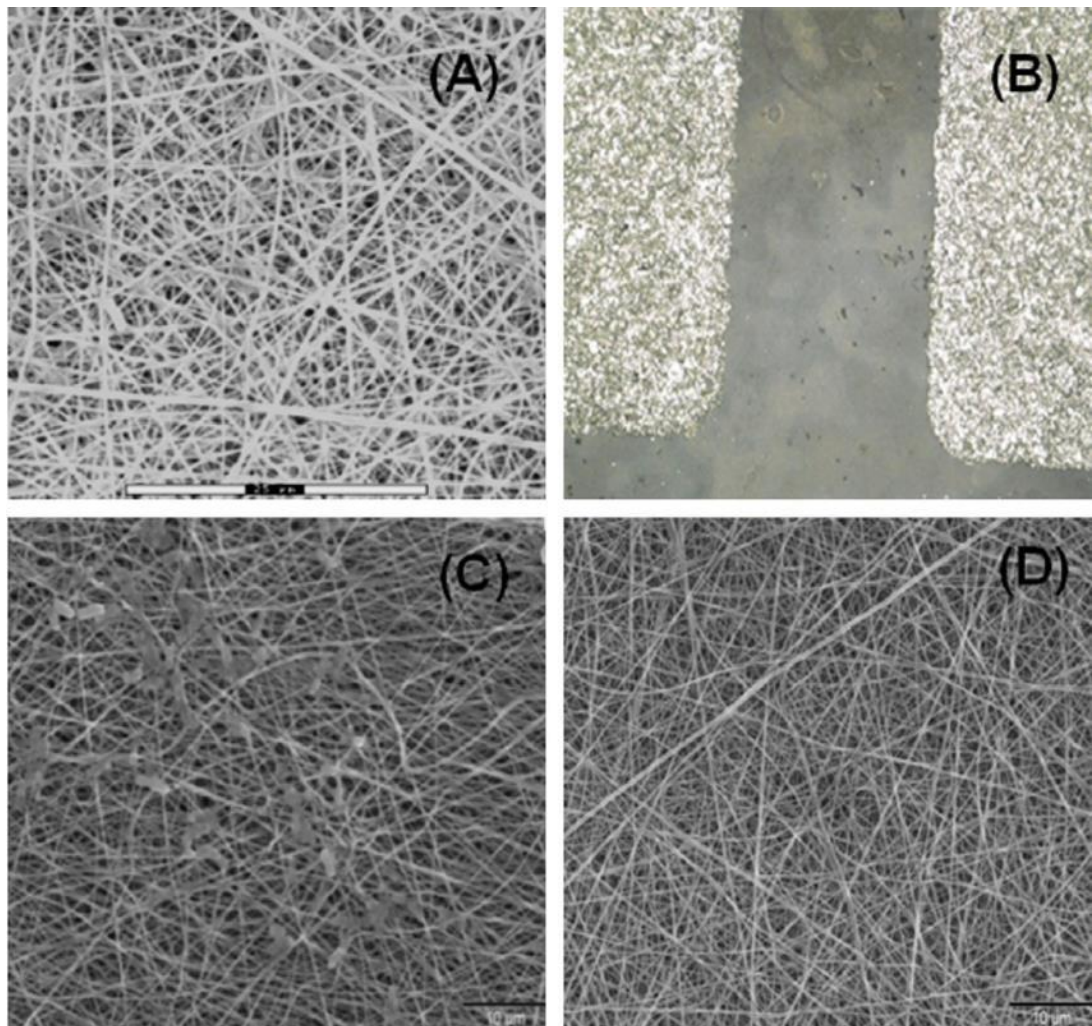

Figure 6. SEM image of nitrocellulose nanofibers(A). Ag electrodes fabricated on the electrospun membrane via spray deposition method (B), SEM image of E. coli O157:H7 captured on the functionalized electrospun mat $(\mathrm{C})$, no bacteria are observed in the non-functionalized nanofiber mat (D) ${ }^{119}$. Copyright 2010, Elsevier. 
(A)
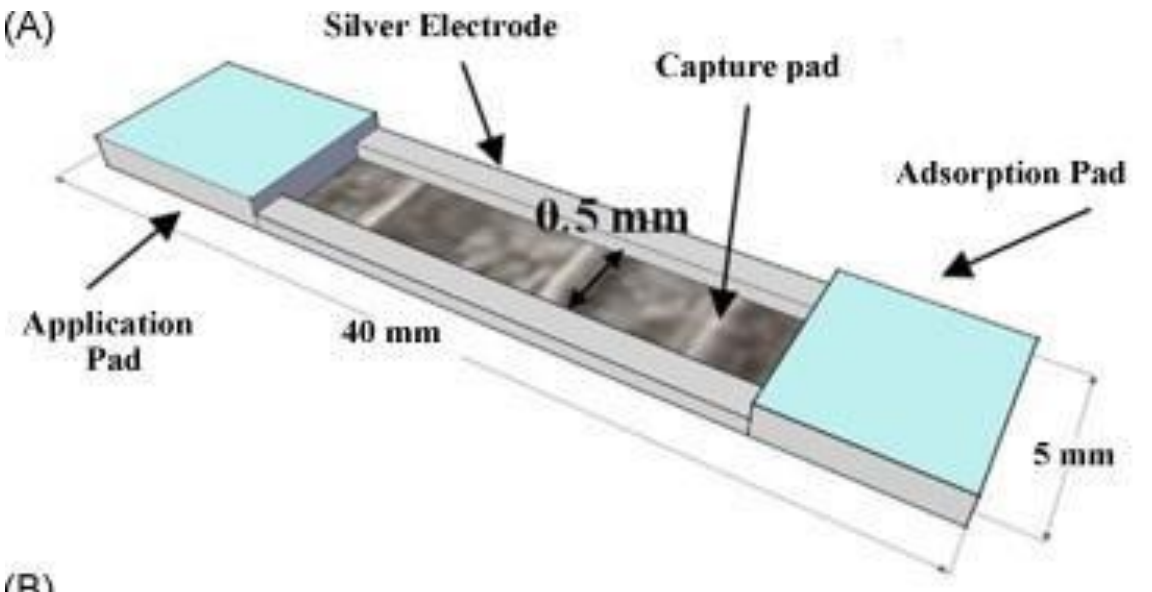

(B)

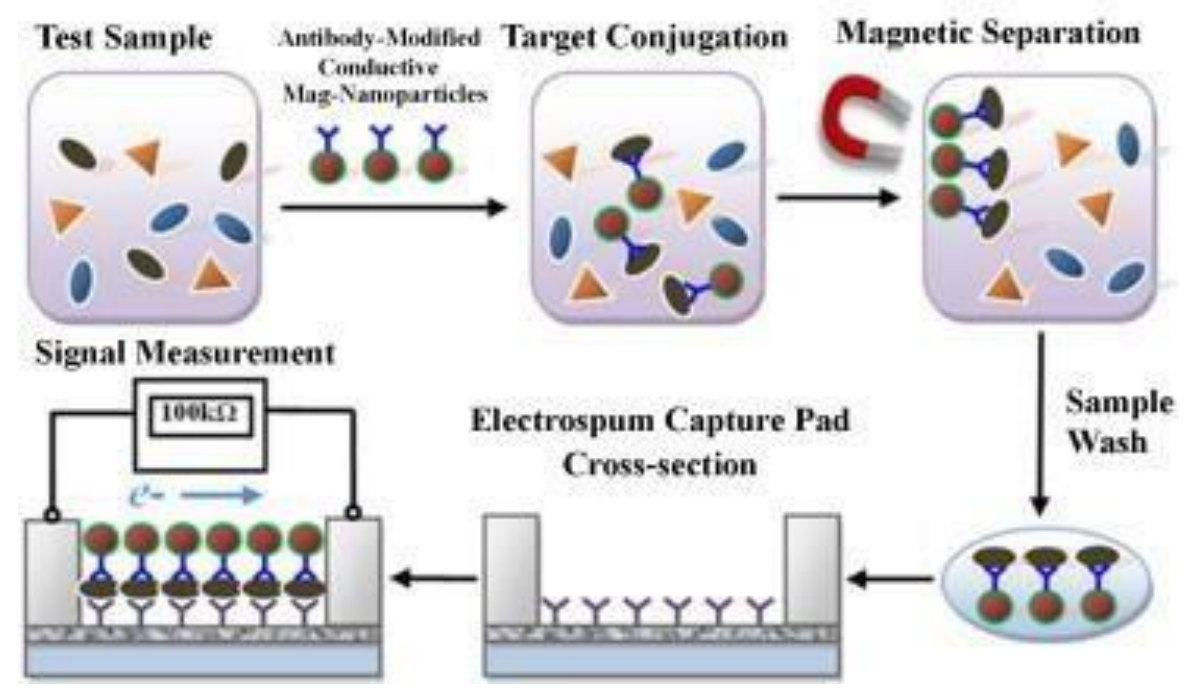

Figure 7. Schematic of the biosensor. (A) structure and membrane assembly consisting of absorption pads and electrospun cellulose nitrate capture pad and cellulose application; and (B) the immunosensor based on the antibody functionalized electrospun capture membrane from the lateral flow (B). ${ }^{119}$ Copyright 2010, Elsevier

Early and accurate diagnosis of diseases has the vital importance to prevent progress or even death of patients, especially in cancers. The presence of biomarkers or variation of their concentrations is the first symptoms of various diseases. Especially during the early stages of the disease, biomarkers concentration are at ultra-low levels. ${ }^{123}$ Nanofiber-based biosensors provide promising horizon on the early cancer detection such as electrochemical biosensor based on CNTs doped nylon6/poly (thionine) (CNT-PA6-PTH) electrospun nanofibers for of K-ras gene mutations 
detection (in concentration just only $30 \mathrm{fM}$ ), ${ }^{124} \mathrm{Pd}$ functionalized $\mathrm{WO}_{3}$ nanofibers as a gas sensor sensitive to toluene in lung cancer detection (Rair/Rgas $=1.32)^{125}$ fluorescent chemosensor based on a dendritic zinc porphyrin (Den-Por(Zn)) electrospun nanofibrous membrane for detection of histamine in urine as a biomarker for cancer detection, ${ }^{126}$ anti-epidermal growth factor receptor conjugated mesoporous zinc oxide nanofibers as an immunosensor with unprecedented sensitivity (femtomolar) to detect a breast cancer, ${ }^{127}$ electrochemical detection of cathepsin B activity in breast cancer cell lysates using carbon nanofiber. ${ }^{128}$ Electrochemical biosensors based on unique properties such as rapid sensing, low cost, portability and ease of use have been offered in the diagnosis of cardiovascular diseases (CVDs).

Biosensors are supposed to have a crucial effect on the early cancer detection, which is due to their low-cost, fast detection, good portability and no side-effects. In addition, with the quick development of nanotechnology, electrospun nanostructures were applied to amplify bioassay signals, which can observably improve the sensitivity and accuracy of biosensors (x). Zhang et al. made a cell capture assay based on anti-EpCAM grafted electrospun $\mathrm{TiO}_{2}$ nanofibers in order to circulate tumor cells detection in colorectal and gastric cancer patients, which significantly enhanced the capture efficiency. ${ }^{129}$ Rezaei et al. summarized researches about the diagnosis of cardiovascular diseases (CVDs) via nanofiber-based electrochemical biosensors. ${ }^{130}$ Miyamoto and his co-workers developed highly gas-permeable, inflammation-free, lightweight and stretchable nanofiber sensors that can be directly laminated onto human skin for long periods of time. The fabricated nanofiber conductors (nanomesh of 300 700 $\mathrm{nm}$ fiber substrates) are made by coating water-soluble high-molecular polyvinyl Alcohol (PVA) alcohol with gold particles. The process of laminating a Au nanomesh onto skin is as follows: first, $\mathrm{Au}$ is evaporated onto electrospun PVA nanofibres; PVA meshes are then dissolved by spraying water; after PVA removal, nanomesh conductors adhere to the skin. The sensor can work as a wireless system that can detect touch, temperature and pressure with excellent mechanical durability. It is no doubt that the nanofiber-based biosensor has become one of the most 
powerful techniques for direct, sensitive, and rapid analysis in medicine to diagnosis, prevent many diseases in the future.
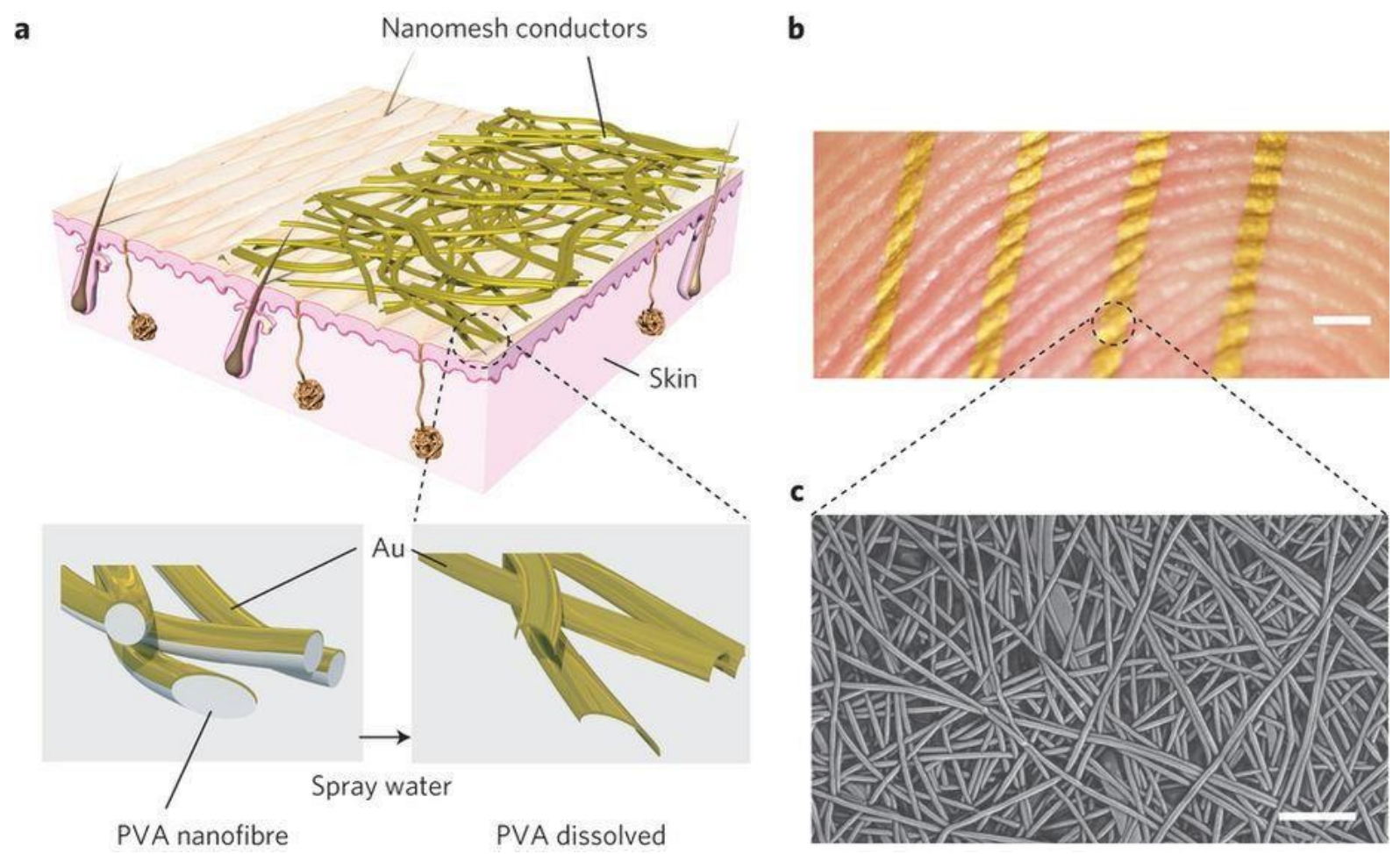

Figure 8. Inflammation-free, gas-permeable, lightweight, stretchable on-skin sensor (electronics) based on nanofiber meshes: (a) A schematic of the Au nanofiber mesh conductors. (b) A picture of $\mathrm{Au}$ nanofiber mesh conductor attached to a fingertip, showing a high level of conformability and adherence to the skin. Scale bar, $1 \mathrm{~mm}$. (c) An SEM image of Au nanofiber mesh conductor formed by dissolving PVA nanofibers. Scale bar, $5 \mu \mathrm{m}(\mathrm{x})$.

\section{Drug Delivery System}

Biomedical application of nanofiber in drug delivery system is growing fast, due to a various number of unique features and properties of porous nanostructure including high drug loading, encapsulation efficiency, enhanced therapeutic index, localized delivery, reduced drug side effects, ability to modulate drug release by engineering, controlling the processing and solution parameters of synthesis. ${ }^{131}$ Nanofibers can be produced from a wide range of natural and synthetic polymers. ${ }^{132}$ 
Nature polymers such as chitosan, cellulose, heparin, gelatin, pectin, collagen, polysaccharides, and proteins. Nanofibers made of natural polymer are biocompatible and more capable of mimicking an extracellular matrix, whereas the synthetic polymers loaded with drugs can be easily electrospun. Although, natural polymers are more expensive than synthetic polymers. Biodegradable polyesters polyglycolic acid (PGA), (polylactic acid (PLA), poly (lactic-co-glycolic) acid (PLGA), and polycaprolactone (PCL), non-biodegradable polyesters(polyurethane (PU), polycarbonate, and nylon-6) and naturally occurring polymers (silk, collagen, gelatin, alginate, and chitosan) prevalently have been used in electrospun fibers for sustained release (Table 3). ${ }^{133,134}$

Simple and versatile fabrication method, high surface-to-volume ratio, interconnected porous structure, the ability to the incorporation of different drugs and high permeability of electrospun nanofibers provide the great potential applications of electrospun nanofibers as an ideal candidate vehicle for drug delivery in medicine. Figure 9 and 10 show various drug incorporation technique to load drugs in/on nanofibers using electrospinning. ${ }^{135}$ Incorporation of the drug can be done easily into electrospun nanofibers by various techniques such as physical adsorption, chemical immobilization, blending, co-axial electrospinning, and emulsion electrospinning. ${ }^{136-140,141}$ 
a

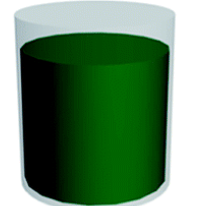

Polymer solution
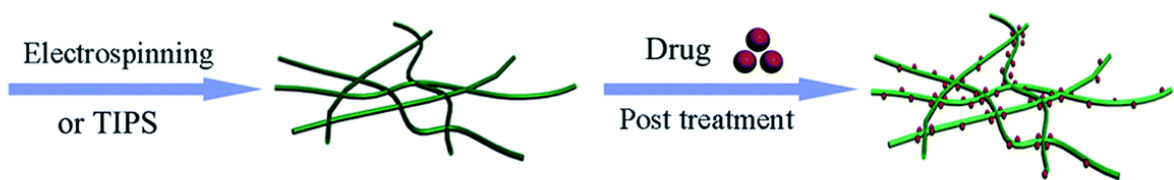

Nanofibers

b
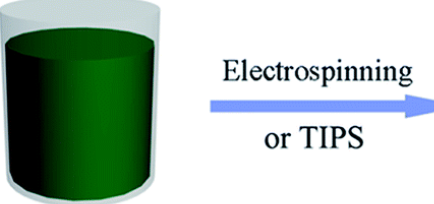

Polymer solution

or TIPS

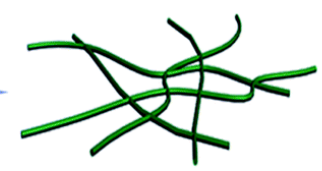

Nanofibers

c

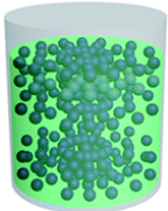

Drug/polymer blends
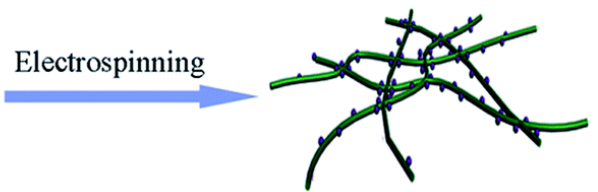

Nanofibers
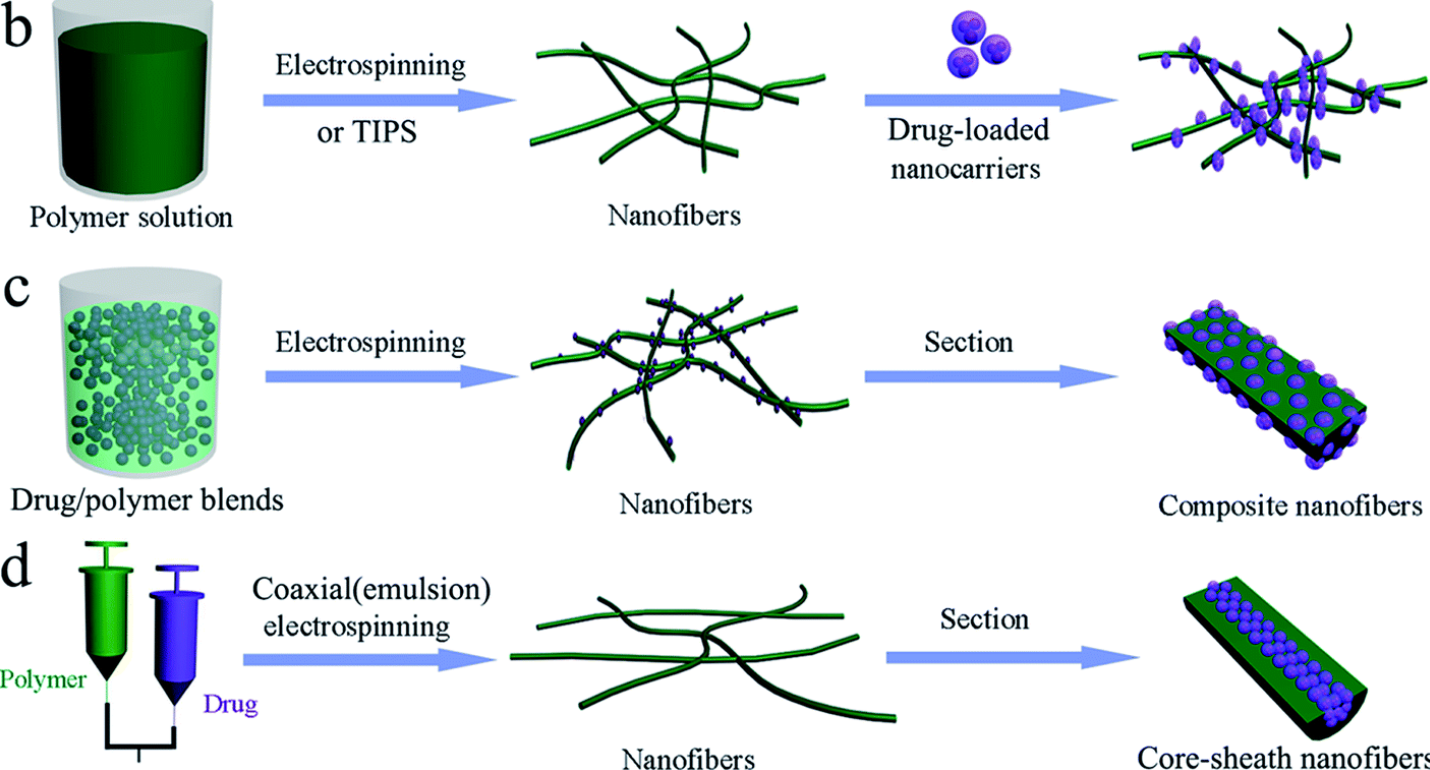

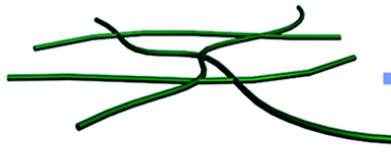

Nanofibers

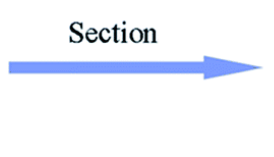

Figure 9. Schematic of possible methods of drug-loading methods in nanofibers: (a) post-treatment of nanofibers; (b) Immobilization of drug/nanocarriers into nanofiber surface. (c) Electrospinning of drugpolymer blends; (d) Coaxial electrospinning of the drug in the core and polymer in the shell. ${ }^{135}$ Copyright 2014, American Chemical Society. 

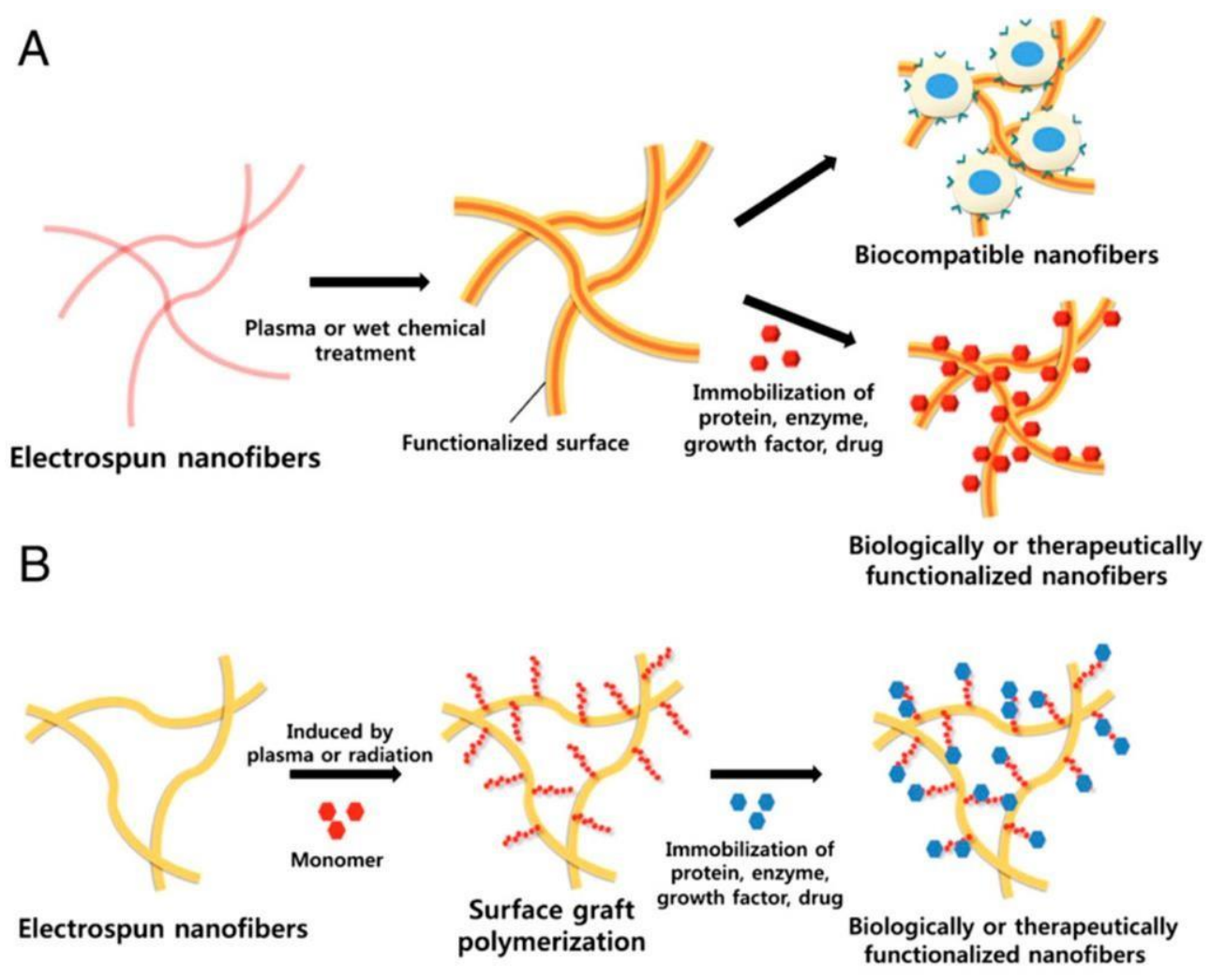

C
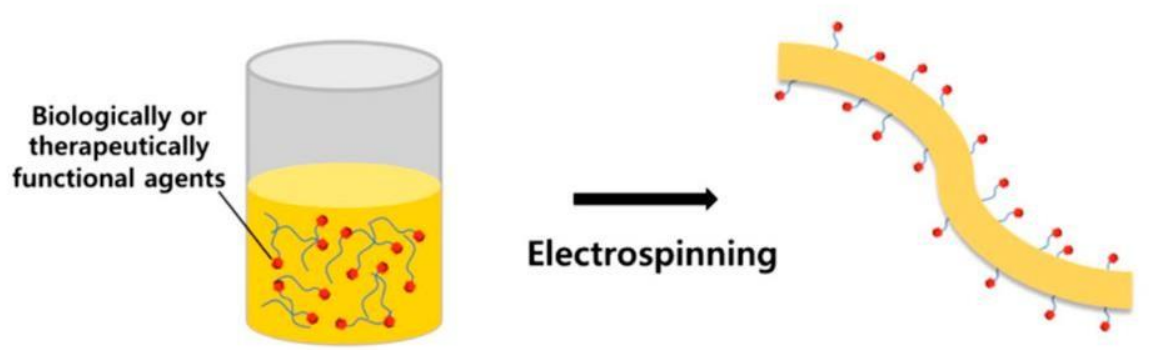

Blend solution

Surface orientation

Figure 10. Different surface immobilization techniques for incorporating biologically active compounds (drugs) into nanofibers: (A) plasma treatment (B) surface graft polymerization (C) coelectrospinning followed by surface orientation. ${ }^{137}$ Copyright 2009, Elsevier.

Recent efforts in electrospinning via fabrication of micro- and nanofibers with structural such as single, coaxial, hollow, porous and triaxial fibers offer ability for encapsulating functional molecules or therapeutic agents, protection the therapeutic agents from the surrounding environment, the possibility of modulate the release kinetics by altering the fiber thickness and localization, maintaining the blood level of the drug between minimum threshold concentration and the toxic 
concentration for an extended period and modulate the mechanical and biological properties of nanofiber. Electrospun fibers in various configurations have been shown in Figure 11. ${ }^{142}$ Co-axial and tri-axial electrospinning techniques resolve the limitations in the traditional drug delivery methods. Medicated nanofibers made by coaxial/triaxial electrospinning provide altered release time profiles according to loading location and distribution of the drug into the nanofibers (Figure 10). ${ }^{142}$
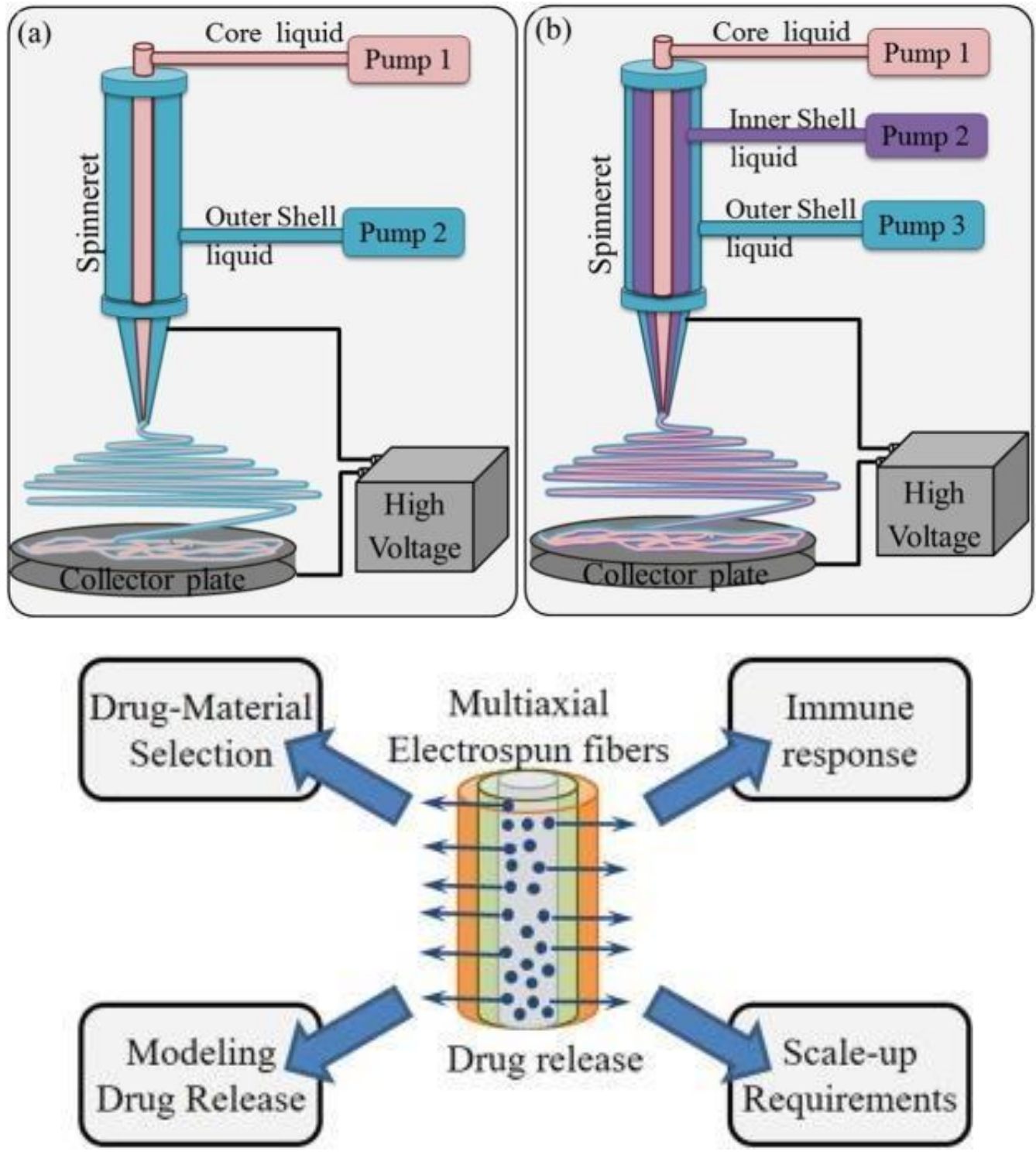

Figure 11. Schematics of a cross-sectional view of electrospun fibers in various configurations: (a) co-axial electrospinning and (b) triaxial electrospinning with the loading of required agents. ${ }^{142}$ Copyright 2017, Elsevier.

Table 3 shows various drug incorporation methods using electrospinning. 


\begin{tabular}{|c|c|c|c|c|}
\hline $\begin{array}{c}\text { Drug } \\
\text { incorporation } \\
\text { methods }\end{array}$ & Advantages & Disadvantages & Example & Ref \\
\hline $\begin{array}{l}\text { Blending } \\
\text { Electrospinning }\end{array}$ & $\begin{array}{l}\text { Simple compared to other } \\
\text { encapsulation methods. } \\
\text { Controlling drug release } \\
\text { by changing the polymer- } \\
\text { polymer ratio in the } \\
\text { blend. }\end{array}$ & $\begin{array}{l}\text { Blended polymers must } \\
\text { be matched } \\
\text { hydrophobic- } \\
\text { hydrophilic properties of } \\
\text { both drug and polymer. } \\
\text { The phase behavior of } \\
\text { the processed polymer } \\
\text { blend is essential should } \\
\text { be known clearly. }\end{array}$ & $\begin{array}{l}\text { Poly(D,L-lactic } \\
\text { coglycolide)(PLGA) } \\
\text { poly(dioxanone)(PDO) } \\
\text { /Ciprofloxacin } \\
\text { hydrochloride (CiH) }\end{array}$ & 143 \\
\hline $\begin{array}{l}\text { Surface } \\
\text { modification } \\
\text { electrospinning }\end{array}$ & $\begin{array}{l}\text { Drugs immobilization on } \\
\text { the nanofiber surface } \\
\text { considered as a workable } \\
\text { solution to combat large } \\
\text { initial burst release and } \\
\text { short release }\end{array}$ & $\begin{array}{l}\text { The nature of polymers } \\
\text { and drugs are crucial } \\
\text { parameters. }\end{array}$ & $\begin{array}{l}\text { PLGA-chitosan mats } \\
\text { were functionalized } \\
\text { with graphene oxide } \\
\text { decorated with silver } \\
\text { nanoparticles }\end{array}$ & 144 \\
\hline $\begin{array}{l}\text { Emulsion } \\
\text { Electrospinning }\end{array}$ & $\begin{array}{l}\text { The process is simple. } \\
\text { The drug and the polymer } \\
\text { are dissolved in } \\
\text { appropriate solvents so } \\
\text { no need for a common } \\
\text { solvent and many } \\
\text { combinations of } \\
\text { hydrophilic drugs and } \\
\text { hydrophobic polymeric } \\
\text { are possible. }\end{array}$ & $\begin{array}{l}\text { Not all kinds of drugs } \\
\text { can be loaded by this } \\
\text { way. In this method, } \\
\text { unstable } \\
\text { macromolecules like } \\
\text { DNA encountered the } \\
\text { shearing force or the } \\
\text { interface tension } \\
\text { between the aqueous } \\
\text { and organic phases of } \\
\text { the emulsion, so for } \\
\text { these reasons, these } \\
\text { macromolecules are } \\
\text { damaged or degraded. }\end{array}$ & $\begin{array}{l}\text { Chitosan/poly(ethylen } \\
\text { e oxide)/ } \\
\text { Cinnamaldehye }\end{array}$ & 145 \\
\hline $\begin{array}{l}\text { Coaxial } \\
\text { Electrospinning }\end{array}$ & $\begin{array}{l}\text { Biomolecule } \\
\text { functionality in the core } \\
\text { is preserved by the shell } \\
\text { polymer. There is no } \\
\text { direct contact between } \\
\text { the core ingredients with }\end{array}$ & $\begin{array}{l}\text { The complexity of the } \\
\text { design and material } \\
\text { parameters. This method } \\
\text { needs a special syringe } \\
\text { tip. }\end{array}$ & $\begin{array}{l}\text { Polycaprolactone@ } \\
\text { chitosan/ silver } \\
\text { nanoparticles }\end{array}$ & 146 \\
\hline
\end{tabular}




\begin{tabular}{|c|c|c|c|c|}
\hline & $\begin{array}{l}\text { the biological } \\
\text { environment. }\end{array}$ & & & \\
\hline $\begin{array}{l}\text { Coaxial } \\
\text { electrospray }\end{array}$ & $\begin{array}{l}\text { Uniform size distribution } \\
\text { high encapsulation } \\
\text { efficiency, effective } \\
\text { protection of drug bio- } \\
\text { functionality }\end{array}$ & $\begin{array}{l}\text { Process control is very } \\
\text { complex due to the } \\
\text { complexity of the } \\
\text { multiple design process, } \\
\text { the metaphysical nature } \\
\text { of the process and } \\
\text { material parameters. }\end{array}$ & $\begin{array}{l}\mathrm{TiO}_{2} / \mathrm{Fe}_{3} \mathrm{O}_{4} \text {, graphene } \\
\text { and quantum dots }\end{array}$ & $\begin{array}{l}147, \\
148\end{array}$ \\
\hline Electrospray & $\begin{array}{l}\text { The possibility of direct } \\
\text { drug incorporating into a } \\
\text { nanofiber in one-step. } \\
\text { It was also proved } \\
\text { considered as a safe } \\
\text { technique for processing } \\
\text { several types of cells. } \\
\text { This method is fast and } \\
\text { easy. Bulk fabrication is } \\
\text { possible. }\end{array}$ & $\begin{array}{l}\text { Sufficient physical } \\
\text { interactions between the } \\
\text { drug and the polymer } \\
\text { are required for attaining } \\
\text { sustained and prolonged } \\
\text { drug release. } \\
\text { Thermal stress in } \\
\text { drying, shearing force in } \\
\text { the nozzle may induce } \\
\text { drug degradation. }\end{array}$ & $\begin{array}{l}\text { PVA/montmorillonite/ } \\
\text { silver hybrid particles }\end{array}$ & 149 \\
\hline
\end{tabular}

Recently, considerable progress has been made in the fabrication of the smart electrospun nanofibers for controlled drug release. In this method, physical and/or chemical stimuli such as $\mathrm{pH}$ value, ionic strength, and temperature, light, electric or magnetic fields, or combinations of them induce the drug release. Smart electrospun nanofiber is gaining considerable attention as an ideal candidate for oral drug delivery, ${ }^{150-152}$ transdermal drug delivery, ${ }^{153-155}$ vaginal drug delivery, ${ }^{156,157}$ and as a scaffold for tissue regeneration due to morphological similarities to the natural extracellular matrix, high surface-to-volume ratios, very high and tunable porosity and good mechanical properties. $^{22,158}$ Another remarkable application of electrospun fibers is their use against infectious diseases treatment. Encapsulated antibiotics or nanoparticles in electrospun fibers exert a potent antimicrobial activity against infectious diseases. ${ }^{159-161}$ Future efforts may be focused on the development of multiple stimuli-responsive electrospun nanofibers. More works need to be done 
related to the biocompatibility of this generation of nanofibers to provide great potential in the biomedical field.

Drugs release from electrospun fibers can be controlled by various factors such as fiber composition, swelling, diameter, porosity, construct, geometry and thickness. ${ }^{162-168}$ A combination of diffusion, polymer degradation, drug partitioning in polymers, and drug dissolution are considered as a drug release mechanism from fibers. The drug release mechanism for the nonbiodegradable matrix is driven by the concentration gradient and osmotic pressure or matrix swelling, for biodegradable matrix or biodegradable matrix with the conjugated drug, the hydrolytic or enzymatic cleavage of the relevant chemical bonds are involved ${ }^{168}$. Some studies of nanofiber in drug delivery are shown in Table 5.

Table 5 shows the therapeutic delivery application of nanofibers.

\begin{tabular}{|c|c|c|c|c|}
\hline Application & Nanofiber & $\begin{array}{c}\text { Therapeutic } \\
\text { Agent }\end{array}$ & Result & Ref \\
\hline \multirow{3}{*}{ 龸 } & $\begin{array}{l}\text { PLA }(\mathrm{MW}=100,000) \text { and } \\
\text { ciprofloxacin conjugated } \\
\text { PLA }\end{array}$ & Ciprofloxacin & $\begin{array}{l}\text { The ciprofloxacin released } \\
\text { from the drug-conjugated } \\
\text { nanofiber possesses } \\
\text { antimicrobial activity } \\
\text { against S. aureus bacteria. }\end{array}$ & 169 \\
\hline & $\begin{array}{l}\text { Halloysite nanotubes } \\
\text { /poly(lactic-co-glycolic } \\
\text { acid) }\end{array}$ & $\begin{array}{l}\text { Tetracycline } \\
\text { hydrochlorid } \\
\text { e (TCH) }\end{array}$ & $\begin{array}{l}\text { The composite nanofibers } \\
\text { display sustained release } \\
\text { manner of the antibacterial } \\
\text { drug for } 42 \text { days }\end{array}$ & 170 \\
\hline & Poly (acrylic acid)(PAA) & DOXY-h & $\begin{array}{l}\text { Streptococcus agalactiae } \\
\text { and Staphylococcus aureus }\end{array}$ & 171 \\
\hline
\end{tabular}




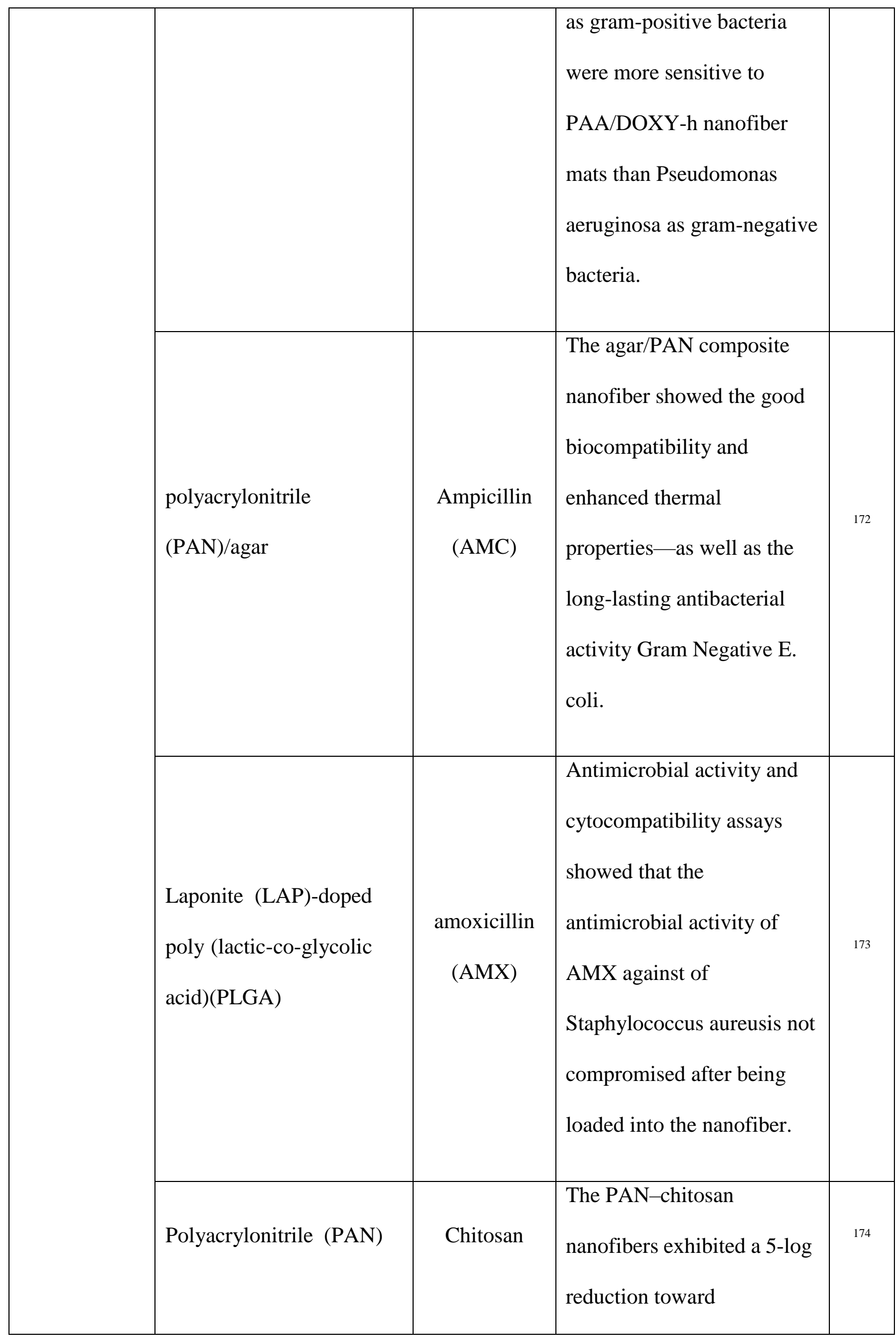




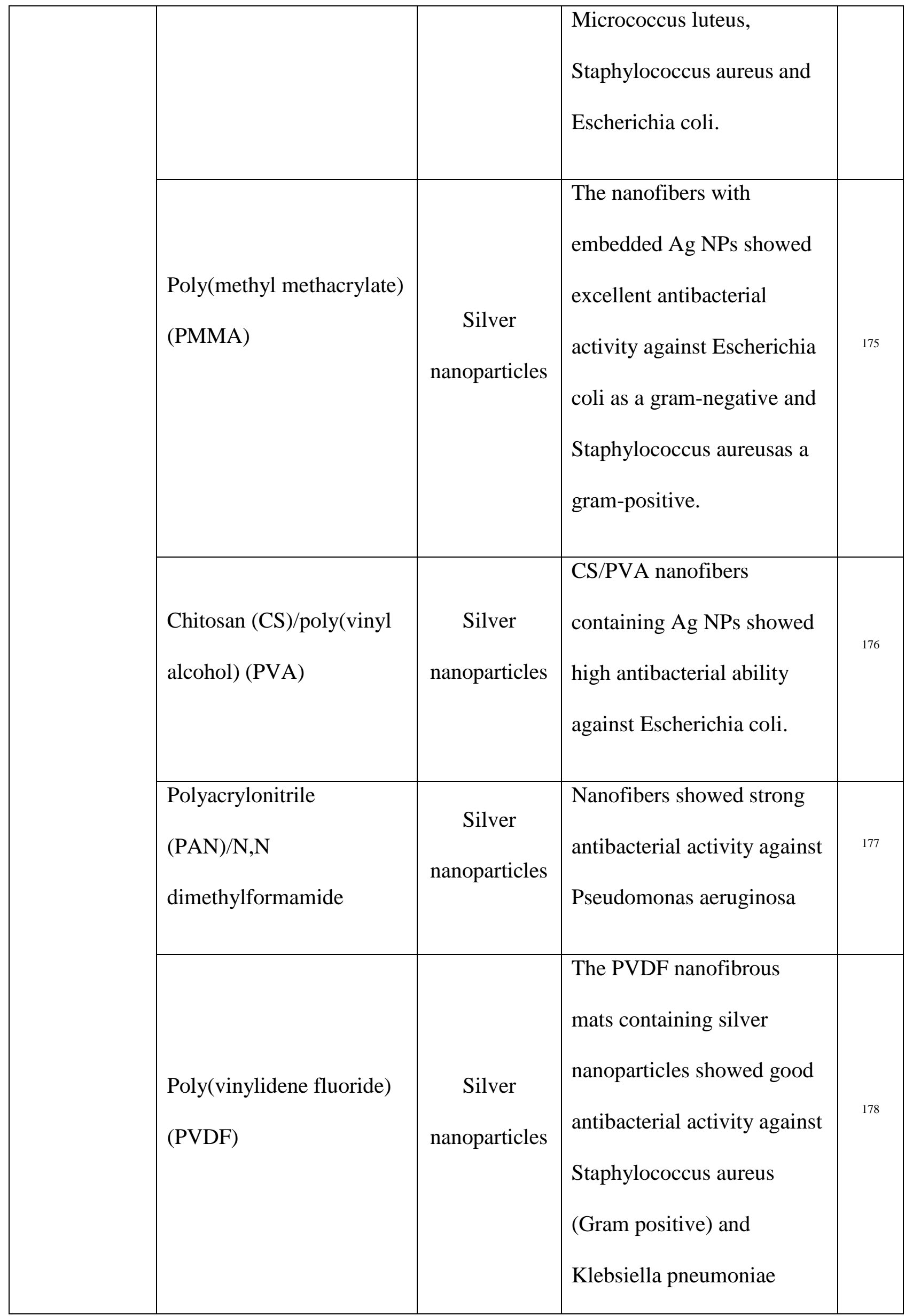




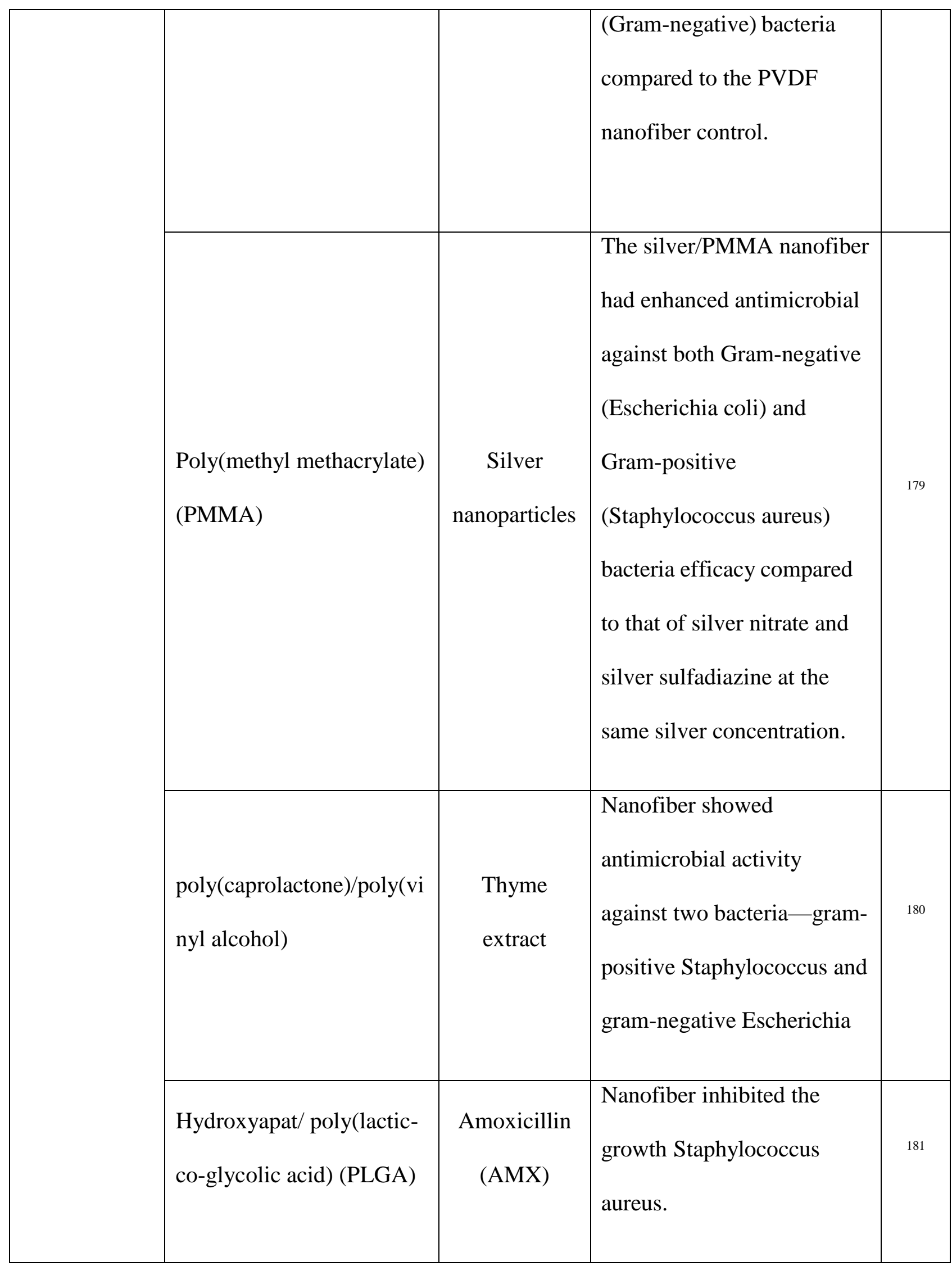




\begin{tabular}{|c|c|c|c|}
\hline polyvinyl alcohol (PVA) & $\begin{array}{l}\text { Allyl } \\
\text { isothiocyanat } \\
\text { e (AITC) }\end{array}$ & $\begin{array}{l}\text { Nanofiber has shown higher } \\
\text { antibac- terialactivity } \\
\text { against Escherichia coli and } \\
\text { Staphylococcus aureus. }\end{array}$ & 182 \\
\hline Chitosan & $\begin{array}{l}\text { Gentamicin } \\
\text { loaded } \\
\text { liposome }\end{array}$ & $\begin{array}{l}\text { Nanofiber showed } \\
\text { bactericidal activity against } \\
\text { Escherichia coli, } \\
\text { Pseudomonas aeruginosa, } \\
\text { and Staphylococcus aureus. }\end{array}$ & 183 \\
\hline $\begin{array}{l}\text { Polycaprolactone@Chitos } \\
\text { an }\end{array}$ & $\begin{array}{c}\text { Silver } \\
\text { nanoparticles }\end{array}$ & $\begin{array}{l}\text { Gram-negative Escherichia } \\
\text { coliBH5 } \alpha \text { (E. coli) and } \\
\text { Gram-positive } \\
\text { Staphylococcus aureus (S. } \\
\text { aureus) were tested against } \\
\text { modified coaxial nanofibers } \\
\text { for antibacterial activity, } 13 \\
\text { mm inhibition zones were } \\
\text { measured against E. coli } \\
\text { which were higher than S. } \\
\text { Aereus. }\end{array}$ & 146 \\
\hline $\begin{array}{l}\text { Poly(lactic acid) (PLA) } \\
\text { and polyvinylpyrrolidone } \\
\text { (PVP) }\end{array}$ & $\begin{array}{l}\text { Copaiba } \\
\text { (Copaifera } \\
\text { sp.) oil }\end{array}$ & $\begin{array}{l}\text { Nanofiber had a greater } \\
\text { antimicrobial action against } \\
\text { Staphylococcus aureus. }\end{array}$ & 184 \\
\hline
\end{tabular}




\begin{tabular}{|c|c|c|c|c|}
\hline & Poly(vinyl alcohol) (PVA) & $\begin{array}{c}\text { Benzyl } \\
\text { triethylammo } \\
\text { nium } \\
\text { chloride } \\
\text { (BTEAC) }\end{array}$ & $\begin{array}{l}\text { BTEAC-PVA nanofibers } \\
\text { successfully inhibited the } \\
\text { growth of Gram-positive } \\
\text { Staphylococcus aureus and } \\
\text { Gram-negative Escherichia } \\
\text { coli and Klebsiella } \\
\text { pneumonia. The BTEAC- } \\
\text { PVA nanofibers inactivated } \\
\text { bacteriophages MS2 and } \\
\text { PhiX174. }\end{array}$ & 185 \\
\hline \multirow{3}{*}{ 苞 } & $\begin{array}{l}\text { PLLA/PEO hydrophilic } \\
\text { polyethylene oxide (PEO) } \\
\text { and hydrophobic poly-L- } \\
\text { lactic acid (PLLA) }\end{array}$ & $\begin{array}{l}\text { Maraviroc } \\
\text { (MVC), } \\
\text { 3'azido-3' } \\
\text { deoxythymidi } \\
\text { ne (AZT), } \\
\text { acyclovir }\end{array}$ & $\begin{array}{l}\text { Fabricated nanofiber meshes } \\
\text { with controlled degradation } \\
\text { kinetics and tunable fiber } \\
\text { size that facilitate } \\
\text { simultaneous release of } \\
\text { multiple drug against sperm, } \\
\text { HIV-1 and HSV-2. }\end{array}$ & 186 \\
\hline & $\begin{array}{l}\text { Poly (L-lactide-co- } \\
\text { glycolide) (PLGA) }\end{array}$ & Griffithsin & $\begin{array}{l}\text { Nanofiber potently inhibit } \\
\text { HIV infection in vitro }\end{array}$ & 187 \\
\hline & $\begin{array}{l}\text { Poly(lactic-co-glycolic } \\
\text { acid) (PLGA) and poly(dl- } \\
\text { lactide-co-E-caprolactone) } \\
\text { (PLCL) }\end{array}$ & $\begin{array}{l}\text { Acyclovir } \\
\text { (ACV) }\end{array}$ & $\begin{array}{l}\text { Nanofiber provided } \\
\text { complete and efficacious } \\
\text { protection against HSV-2 } \\
\text { infection in vitro }\end{array}$ & 188 \\
\hline
\end{tabular}




\begin{tabular}{|c|c|c|c|c|}
\hline & Poly(vinyl alcohol) (PVA) & $\begin{array}{l}\text { Tenofovir } \\
\text { (TFV) }\end{array}$ & $\begin{array}{l}\text { The results support the } \\
\text { potential for scale-up of } \\
\text { TFV-loaded fibers against } \\
\text { HIV-1. }\end{array}$ & 189 \\
\hline \multirow{4}{*}{ 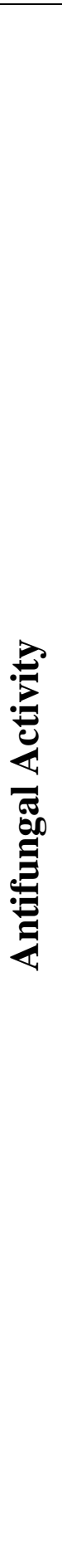 } & $\begin{array}{l}\text { Poly(vinyl alcohol)/ } \\
\text { Poly(methyl methacrylate) } \\
\text { (PVP/PMMA) }\end{array}$ & $\begin{array}{l}\text { cetylpyridini } \\
\text { m chloride } \\
\text { (CPC) }\end{array}$ & $\begin{array}{l}\text { Nanofiber had antifungal } \\
\text { action against C. albicans }\end{array}$ & 190 \\
\hline & Polycaprolactone (PCL) & $\begin{array}{l}\text { Egg lecithin } \\
\text { and } \\
\text { terbinafine } \\
\text { hydrochlorid } \\
\text { e } \\
\text { (terbinafine) }\end{array}$ & $\begin{array}{l}\text { Nanofiber showed } \\
\text { antifungal efficacy against } \\
\text { moulds as well as } \\
\text { dermatophytic fungus }\end{array}$ & 191 \\
\hline & Poly-e-caprolactone & ketoconazole & $\begin{array}{l}\text { Functionalized nanofibers } \\
\text { exhibited antifungal activity } \\
\text { toward Aspergillus flavus, } \\
\text { A. niger, A. carbonarius, } \\
\text { Aspergillus sp. A29, } \\
\text { Penicillium citrinum and } \\
\text { Fusarium oxysporum. }\end{array}$ & 192 \\
\hline & $\begin{array}{l}\text { Polyethylene oxide and } \\
\text { polycaprolactone }\end{array}$ & Clotrimazole & $\begin{array}{l}\text { In vitro antifungal study } \\
\text { suggested its therapeutic } \\
\text { effectiveness in the }\end{array}$ & 193 \\
\hline
\end{tabular}




\begin{tabular}{|c|c|c|c|c|c|}
\hline \multirow[b]{3}{*}{ 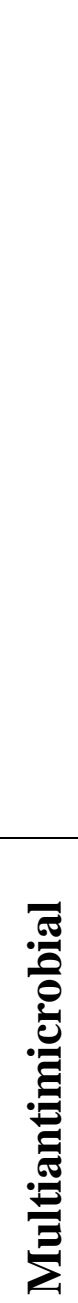 } & & & & $\begin{array}{l}\text { treatment of oral } \\
\text { candidiasis. }\end{array}$ & \\
\hline & & $\begin{array}{l}\text { Polycaprolactone }(\mathrm{PCL}) / \\
\text { Gelatin }\end{array}$ & $\begin{array}{l}\text { terbinafine } \\
\text { hydrochlorid } \\
\text { e (TFH) }\end{array}$ & $\begin{array}{l}\text { Nanofiber showed } \\
\text { antifungal activity against } \\
\text { Trichophyton } \\
\text { mentagrophytes, Aspergillus } \\
\text { fumigatus and Candida } \\
\text { albicans }\end{array}$ & 194 \\
\hline & : & Chitin & $\begin{array}{c}\text { Silver } \\
\text { nanoparticles }\end{array}$ & $\begin{array}{l}\text { Chitin/Ag nanofiber showed } \\
\text { much stronger antimicrobial } \\
\text { properties against E. coli, P. } \\
\text { aeruginosa, and influenza A } \\
\text { virus. }\end{array}$ & 195 \\
\hline 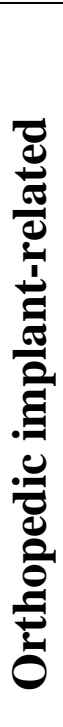 & : & $\begin{array}{l}\text { Poly(D,L-lactic acid-co- } \\
\text { glycolic acid) (PLGA) }\end{array}$ & $\begin{array}{l}\text { Fusidic acid } \\
\text { (FA) and } \\
\text { rifampicin } \\
\text { (RIF) }\end{array}$ & $\begin{array}{l}\text { All dual-loaded } \\
\text { formulations exhibited } \\
\text { direct antimicrobial activity } \\
\text { in vitro against two strains } \\
\text { of methicillin-resistant } \\
\text { Staphylococcus } \\
\text { aureus(MRSA) and } \\
\text { Staphylococcus epidermidis. }\end{array}$ & 19 \\
\hline 苍 & : & $\begin{array}{l}\text { Poly(d,l-lactide-co } \\
\text { glycolide)-poly( } \varepsilon^{-} \\
\text {caprolactone })\end{array}$ & Quercetin & $\begin{array}{l}\text { Nanofiber showed the } \\
\text { antibiofilm activity against } \\
\text { Candida albicans. }\end{array}$ & 196 \\
\hline
\end{tabular}




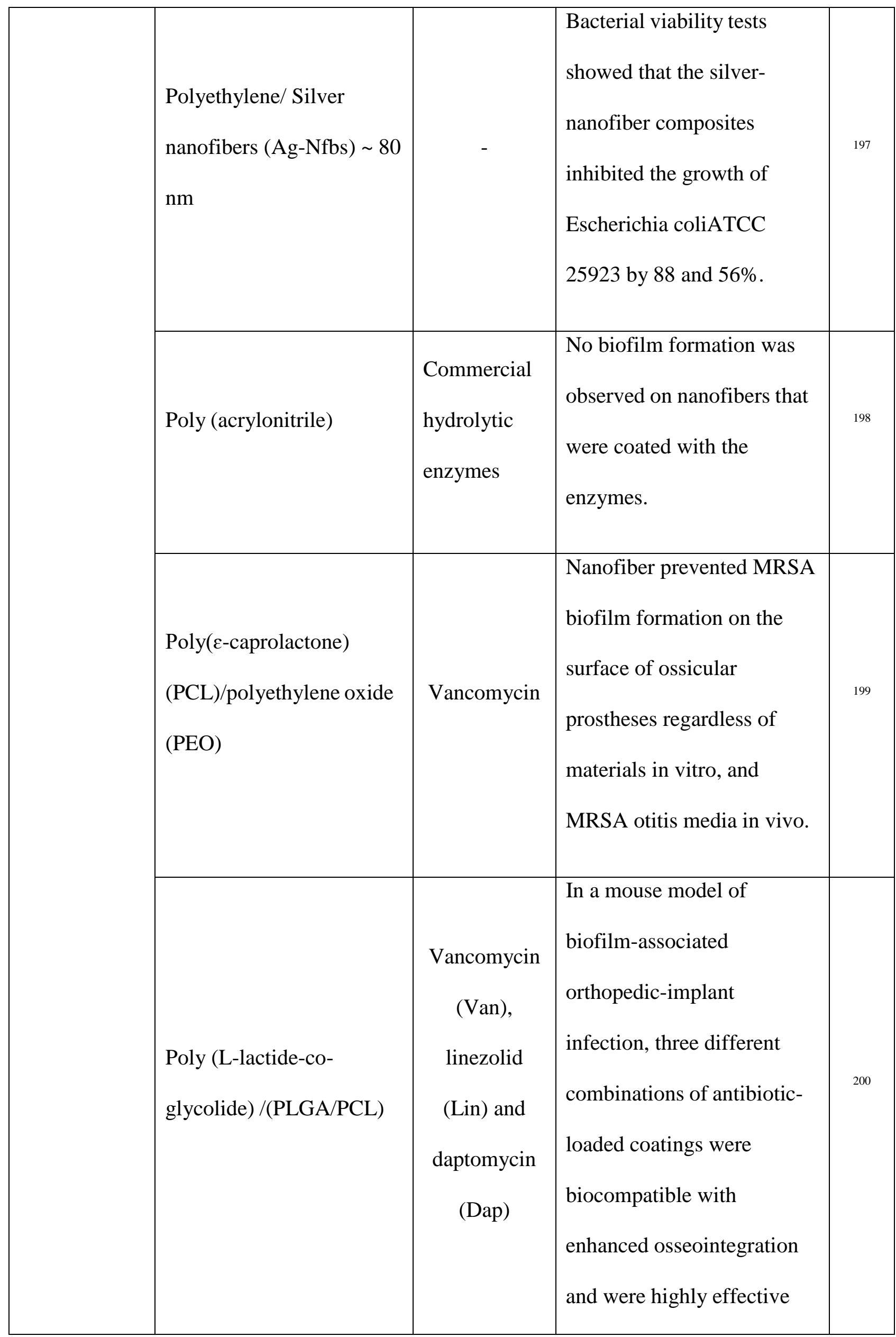




\begin{tabular}{|c|c|c|c|c|c|}
\hline & & & & $\begin{array}{l}\text { implant biofilm formation } \\
\text { and in preventing infection } \\
\text { of the bone/joint tissue }\end{array}$ & \\
\hline 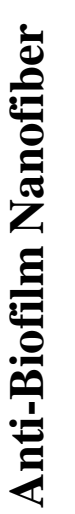 & 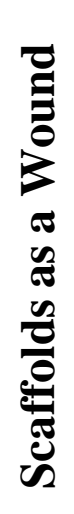 & $\begin{array}{l}\text { Poly-D, L-lactide } \\
\text { (PDLLA) and poly } \\
\text { (ethylene oxide) (PEO) }\end{array}$ & $\begin{array}{l}\text { Copper } \\
\text { particles }\end{array}$ & $\begin{array}{l}\text { After } 48 \text { h biofilm formation } \\
\text { by S.aureus Xen } 30 \text { and P. } \\
\text { aeruginosa PA01S was } \\
\text { reduced by } 50 \% \text { a nd } 41 \% \text {, } \\
\text { respectively }\end{array}$ & 201 \\
\hline \multirow[b]{2}{*}{ 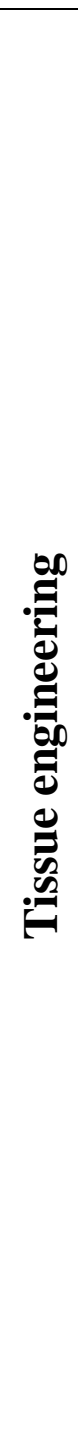 } & & $\begin{array}{l}\text { Poly (L-lactide-co- } \\
\text { glycolide) / (PLGA/ } \\
\text { PLLA) }\end{array}$ & $\begin{array}{l}\text { Doxycycline } \\
\text { (DOXY) }\end{array}$ & $\begin{array}{l}\text { In vitro antibacterial tests } \\
\text { scaffold confirmed its } \\
\text { ability to prevent common } \\
\text { bacterial growth (E. coli and } \\
\text { S. aureus) for a prolonged } \\
\text { duration. }\end{array}$ & 15 \\
\hline & & $\begin{array}{l}\text { Poly(1-caprolactone) } \\
\text { (PCL/gelatin) }\end{array}$ & $\begin{array}{c}\text { Metronidazol } \\
\text { e }\end{array}$ & $\begin{array}{l}\text { The controlled and } \\
\text { sustained release manner of } \\
\text { the drug from the membrane } \\
\text { significantly prevented the } \\
\text { anaerobic bacteria } \\
\text { colonization. Until the drug } \\
\text { content reached } 30 \% \text {, cells } \\
\text { could adhere to and } \\
\text { proliferate on the }\end{array}$ & 16 \\
\hline
\end{tabular}




\begin{tabular}{|c|c|c|c|c|}
\hline & & & & $\begin{array}{c}\text { membranes without } \\
\text { cytotoxicity. }\end{array}$ \\
\hline 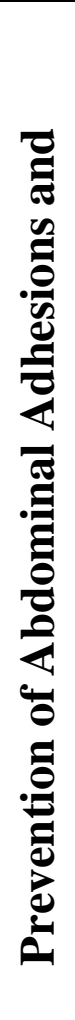 & 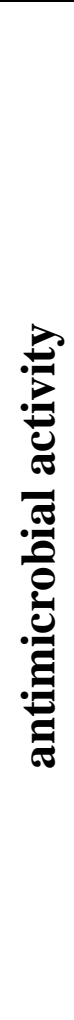 & Caprolactone(PCL) & Biteral & $\begin{array}{l}\text { Microscopical and } \\
\text { histological evaluations } \\
\text { exhibited that using these } \\
\text { barriers reduces the extent, } \\
\text { type, and tenacity of } \\
\text { adhesion. The antibiotic } \\
\text { embedded membranes } \\
\text { significantly eradicated } \\
\text { postsurgery abdominal } \\
\text { adhesions, and also } \\
\text { improved healing. }\end{array}$ \\
\hline
\end{tabular}

\section{Nanofibers for Wound Healing and Skin Care}

Many researchers are currently conducted to achieve proper wound dressing's materials to simultaneously fight infection while improving tissue healing without the development of resistant bacteria. Electrospun nanofibers show immense potential in wound healing. Electrospun nanofiber mats provide a structure like native extracellular matrix with high interconnected porosity (60$90 \%),{ }^{37}$ great absorbancies, water absorbance capacity of nanofiber is between $18-213 \%$ more than films that fabricated from the same polymers, ${ }^{140}$ balanced moisture and gas permeability bring an appropriate environment to protect the wound from exogenous infection, cell migration and proliferation, hemostasis, exudate absorption and cell respiration. Electrospun nanofibers can regulate skin cell responses including proliferation, migration, differentiation and native extracellular matrix 
deposition. The wound healing ability of nanofibers is shown in Figure 11. The wound healing of the mouse was efficiently cured by electrospun nanofibers within 14 days. ${ }^{203}$

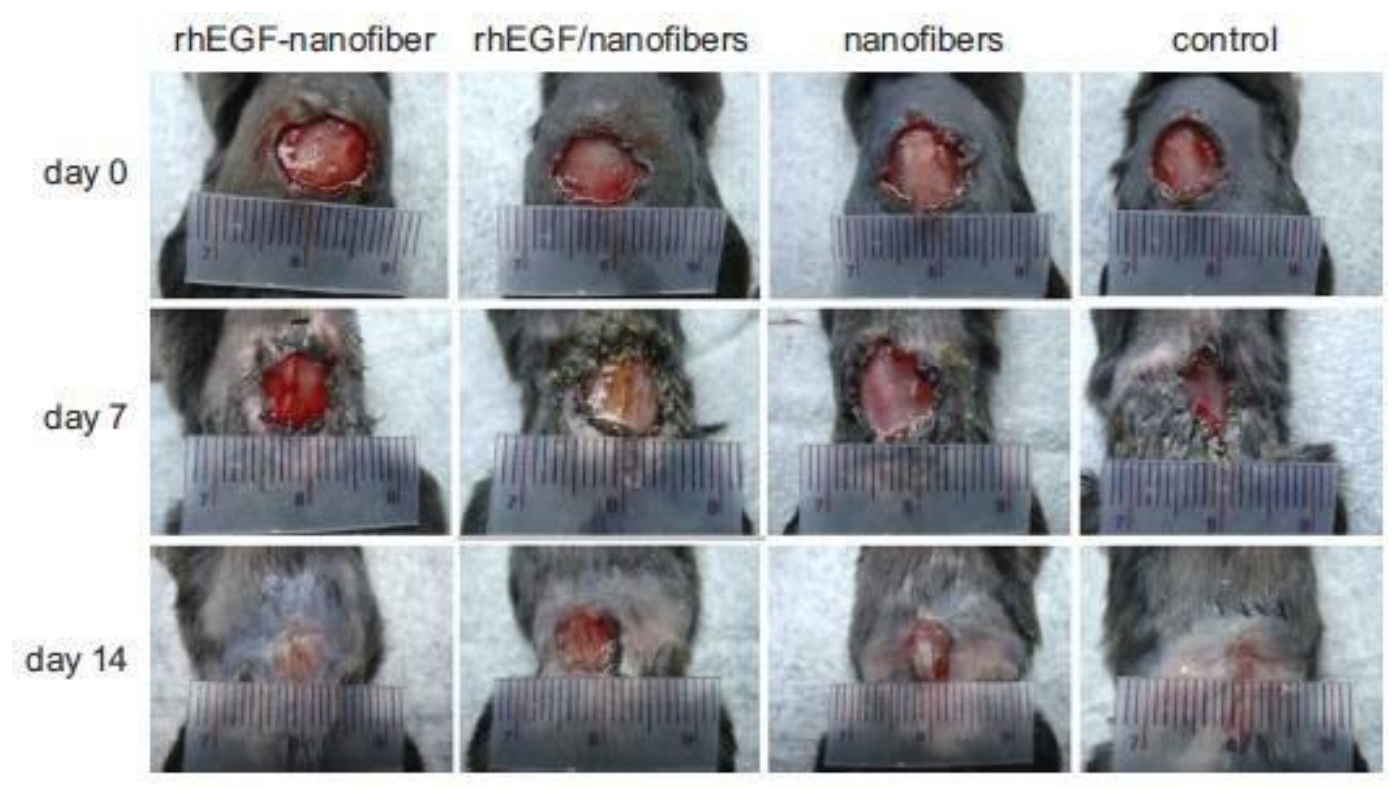

Figure 11. Extent of nanofiber wound healing ability in diabetic C57BL/6 mice treated with various formulations. ${ }^{204}$ Copyright 2008, Elsevier.

Loading antimicrobials agents, growth factors, vitamins and drugs into nanofibers provides a great potential in the development of an effective antimicrobial system able to treat infections in the wound regions, prohibition of bacterial biofilm formation, prolonging drug release and decreasing the time of wound healing process. ${ }^{38-40,} 205-207$ Collagen, ${ }^{69,208}$ polyvinyl alcohol, ${ }^{209}$ polyvinylpyrrolidone,${ }^{210,211}$ polyacrylic acid, ${ }^{212,213}$ gelatin, ${ }^{214}$ chitosan, ${ }^{215}$ silk fibroin, ${ }^{17}$ polyesters and polyurethane ${ }^{40}$ have been used to fabricate nanofibrous materials as a wound dressing. There is need to attain smart nanofiber with the ability to provide optimal drug release profiles and rates of release according to the type of wound, the conditions of the wound and subsequently, start the release of drug agents with the optimum delivery profile only when needed to treat in the wound region. An initial burst effect is toxic to tissue cells. ${ }^{22,74}$ However, now these systems are not available. Recently many researchers have focused to achieve these smart systems and translate them into an effective wound healing. ${ }^{216-218}$ The effects of different layered nanofiber matrices are presented in Figure 12 
and the ability of the scaffold was evaluated. ${ }^{204}$ The new generation of smart electrospun nanofibers with electrical stimulation, mechanical stress and pulsed magnetic field could enhance and accelerate wound healing. ${ }^{219-221}$ Interestingly, the scaffolding application of electrospun nanofiber mats has already been applied on the industrial scale.

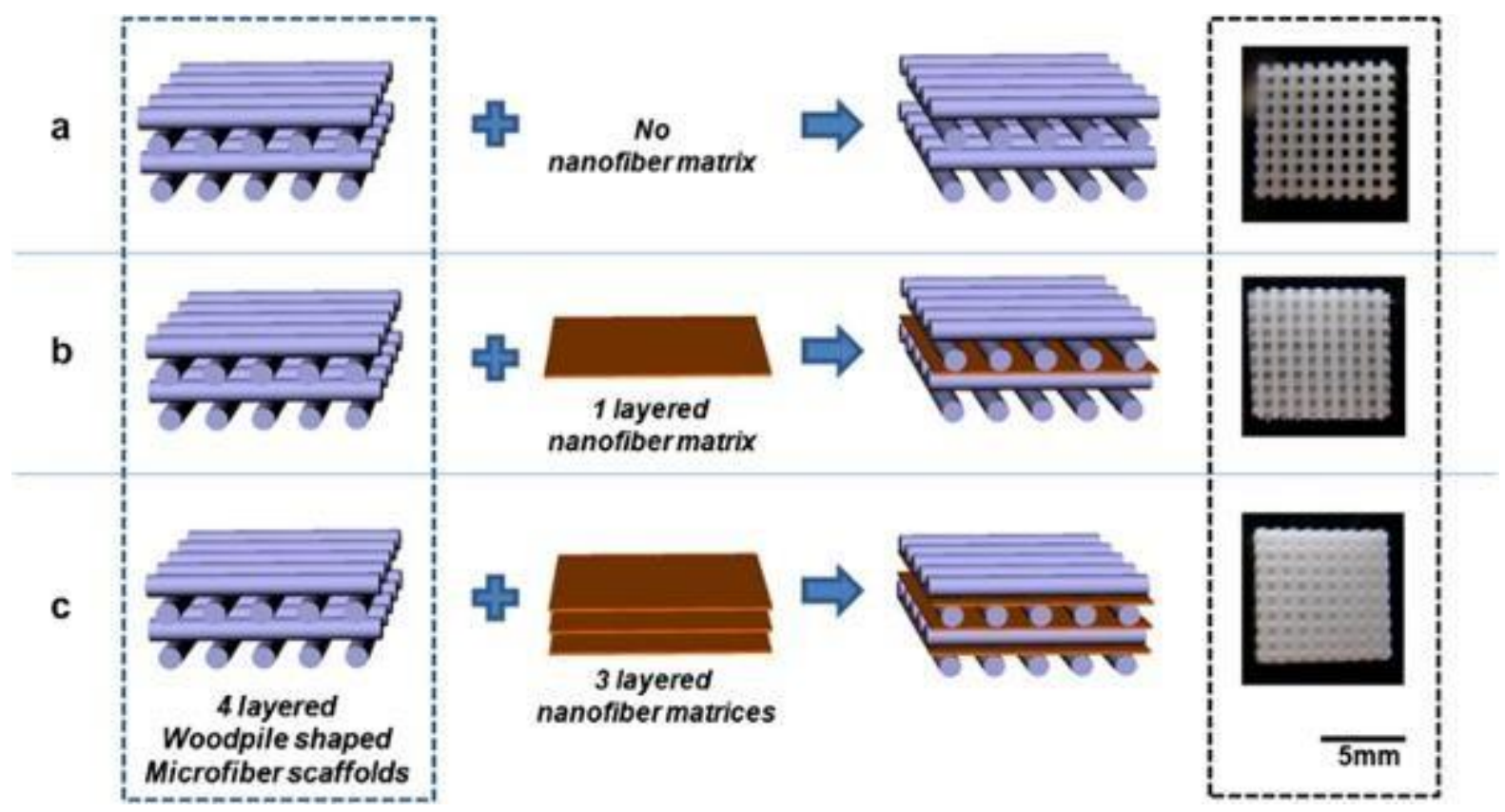

Figure 12. Different types of hybrid micro/nanofiber scaffolds employed in the cell culture tests. (a) Scaffold matrix has no nanofiber matrix and only a PCL scaffold as a control specimen. (b) Scaffold matrix made of a one-layer PCL/collagen nanofiber matrix and (c) Scaffold matrix made of a threelayer PCL/collagen nanofiber matrix ${ }^{204}$. Copyright 2008, Elsevier.

Electrospinning provides the great potential for various application in the cosmetic market such as for skin health and renewal such as skin healing, skin therapy and facial masks for skin cleansing. ${ }^{263-}$ 267. The nanofibers mat considered as a vehicle for incorporating active ingredients with the controlled release in some cases to cosmetic applications. Fathi-Azarbayjani et.al have developed polymeric nanofiber face mask made of PVA and RM $\beta-C D$ that incorporated with several skin nutrients such as ascorbic acid, retinoic acid, gold, and collagen. In comparison with commercial available facial cotton masks, the large surface area to volume ratio of the nanofiber mask will guarantee maximum contact with the skin surface and help to enhance the skin permeation to restore its healthy 
appearance, this face mask will only be wetted when applied to the skin, so improving product stability. When moistened, the content of the mask will gradually dissolve and the active ingredients will release and provide maximum skin penetration. ${ }^{268}$ It seems that nanofibers will get more attention due to their unique features in this specific application in the cosmetics market in the future.

\section{Nanofiber for ultrafiltration of air, water and blood}

Nanofiber filtration membranes represent the next generation nonwoven filter media due to their unique properties. Nanofiber membranes allow for the fabrication of filtration media capable of retaining contaminants as small as 200 nanometers, including viruses, bacteria, multivalent ions and ultrafine particulate. One of the drawbacks is the high-pressure drop over the nanofiber membrane. To use in ultrafiltration, the nanofiber membranes are used with a supporting substrate to prevent membrane rupturing under high pressure.

Water pollution has many facets, and the resultant health risks. Drinking water can expose people to a variety of harmful pollutants and pathogens such as heavy metals $\left(\mathrm{Cu}^{2+}, \mathrm{Pb}^{2+}, \mathrm{Ni}^{2+}, \mathrm{Cd}^{2+}\right)$, toxic organic compounds, bacteria and viruses. According to WHO report, about 2.1 billion people lack safe drinking water at home..$^{222,223}$ Thus there are essential needs to remove environmental contaminations from water. Nanofiber membranes bring effective solution for removing of pollutants from water. Nanofibrous membranes have an extremely high surface-to-volume ratio, small pore size, high porosity and permeability, easy surface functionalization. They are very effective in removing viruses, ${ }^{250}$ antibiotics, metal nanoparticles ${ }^{251-253}$, bacteria, and microorganisms from water. ${ }^{254,255}$ Water membrane biofouling has a negative effect on membrane performance. To solve this problem, membrane surface was modified using biocidal agents $(\mathrm{x})$. Commercial ultrafiltration membranes were therefore modified using polymeric nanofibers in order to gain additional water treatment 
functionality. Current research is focused on the surface membrane modification with different types of polymeric nanofibers, photocatalysts, and biodegradable substances (x).

Many attempts have been conducted to reduce the carcinogenic effect of air pollution with viruses, bacteria, toxic gases, and pathogenic bioaerosols. The penetration of these particulates into the respiratory system, in long-term exposure, can cause too many serious health problems. ${ }^{257}$ Several studies have proved that nanofiber membranes have excellent ability in filtering viruses, bacteria, toxic gases, and pathogenic bioaerosols from air. ${ }^{258-260,261,262}$ Face mask fabricated made of nanofiber membrane provide an effective protection against various airborne pathogens. Some of these nanofibrous face masks are already in the market, e.g. RespiPro ${ }^{\circledR}$ mask. On the lab scale, Zhang et al. ${ }^{259}$ have designed polyacrylonitrile nanofiber/ ZIF-8 as a metal-organic framework filters (PAN /ZIF8) for air pollutants control. The nanofibrous filters (so called MOFilter) has showed high particulate matter removal efficiencies up to $89.6 \%$ and $88.3 \%$ for PM10 and PM2.5 for over 48 h of continuous, respectively. Figure 14 shows the suggested capture mechanism of the air pollutants and SEM Image of the MOFilter before and after long-term PM capture. ${ }^{259}$ The suggested capture mechanism of the air pollutants by the MOFilter can be done by three mechanisms: (i) binding to the open metal sites on MOFs; (ii) interacting with the functional groups on MOFs and/or polymers; (iii) electrostatic interactions with MOF nanocrystals.

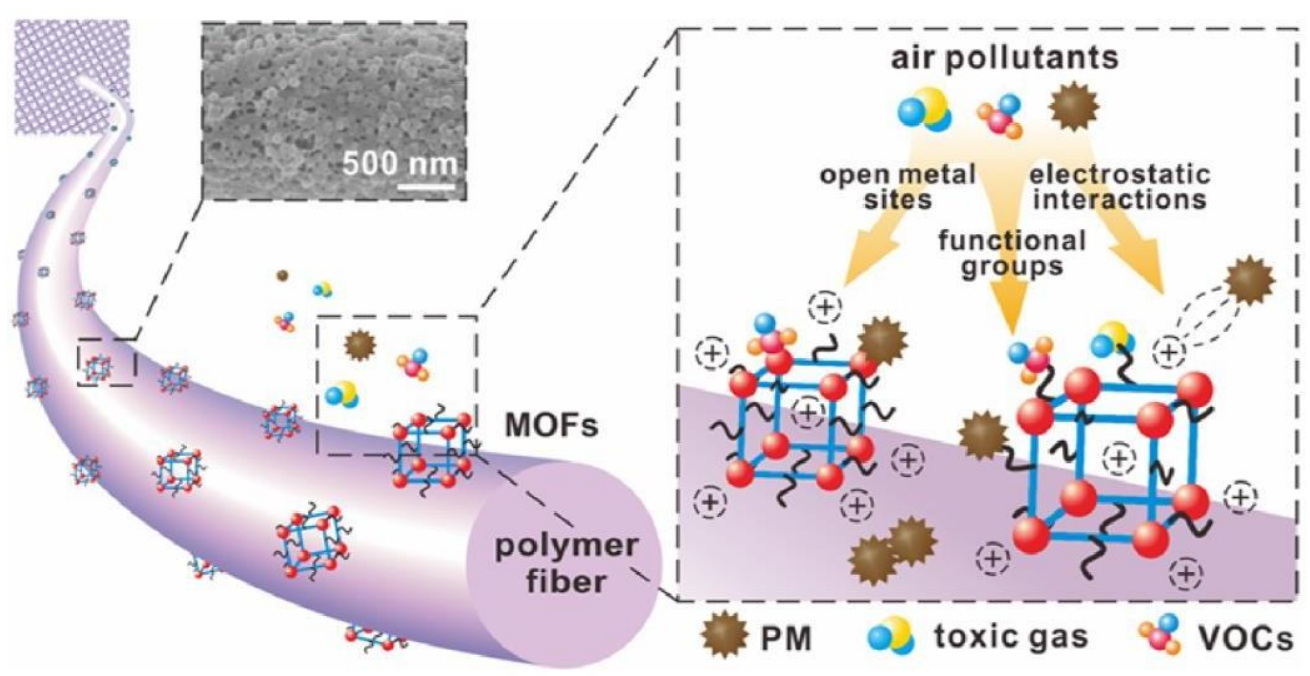




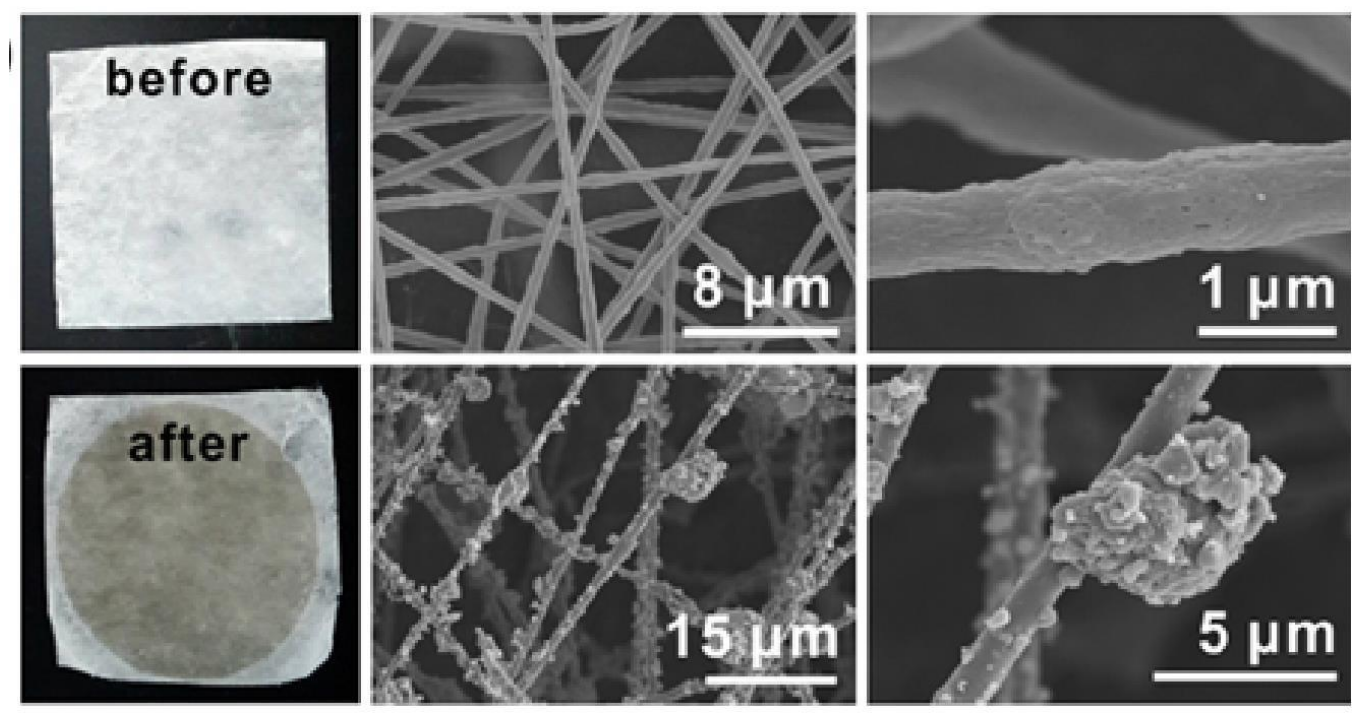

Figure 14. (a) suggested capture mechanism of the air pollutants and Inset is the SEM image the MOF/polymer composite fiber surface.; (b) Photos and SEM images of the ZIF-8/PAN MOFilter before and after PM capture. ${ }^{259}$ Copyright 2016, American Chemical Society.

Electrospun fibers as ideal materials for gas maks and protective clothings to protect against nanoparticulate aerosols, chemicals and biological threats (which include chemicals like: nerve agents, mustard gas, blood agents such as cyanides, and biological toxins such as bacterial spores, viruses, and rickettsiae). ${ }^{269,270}$ Faccini et al. have developed nanofibrous mats of polyamide 6 (PA6) were deposited onto a nonwoven viscose substrate as a protective clothing against nanoparticulate aerosols protective clothing against nanoparticulate aerosols. ${ }^{269}$ Agarwal et al. fabricated the detoxicification performance of zeolite catalysts (Linde Type A and Mordenite) coated onto cellulose/polyethylene terephthalate (PET) electrospun nanofibers against paraxon, a nerve agent stimulant. $^{271}$

Kidney or renal failure is a debilitating condition in which the kidneys are no longer able to remove enough waste and excess fluid from the body. Namekawa et al.(x) developed a zeolitepolymer composite nanofiber membrane to remove uremic toxins for blood purification. The nanofiber membrane is composed of blood compatible poly(ethylene-co-vinyl alcohol) (EVOH) as 
the primary matrix polymer and zeolites which are capable of selectively adsorbing uremic toxins such as creatinine. The proposed composite fibers have the potential to be utilized as an innovative approach to removing nitrogenous waste products from the bloodstream without the requirement of specialized equipment (Figure 15).

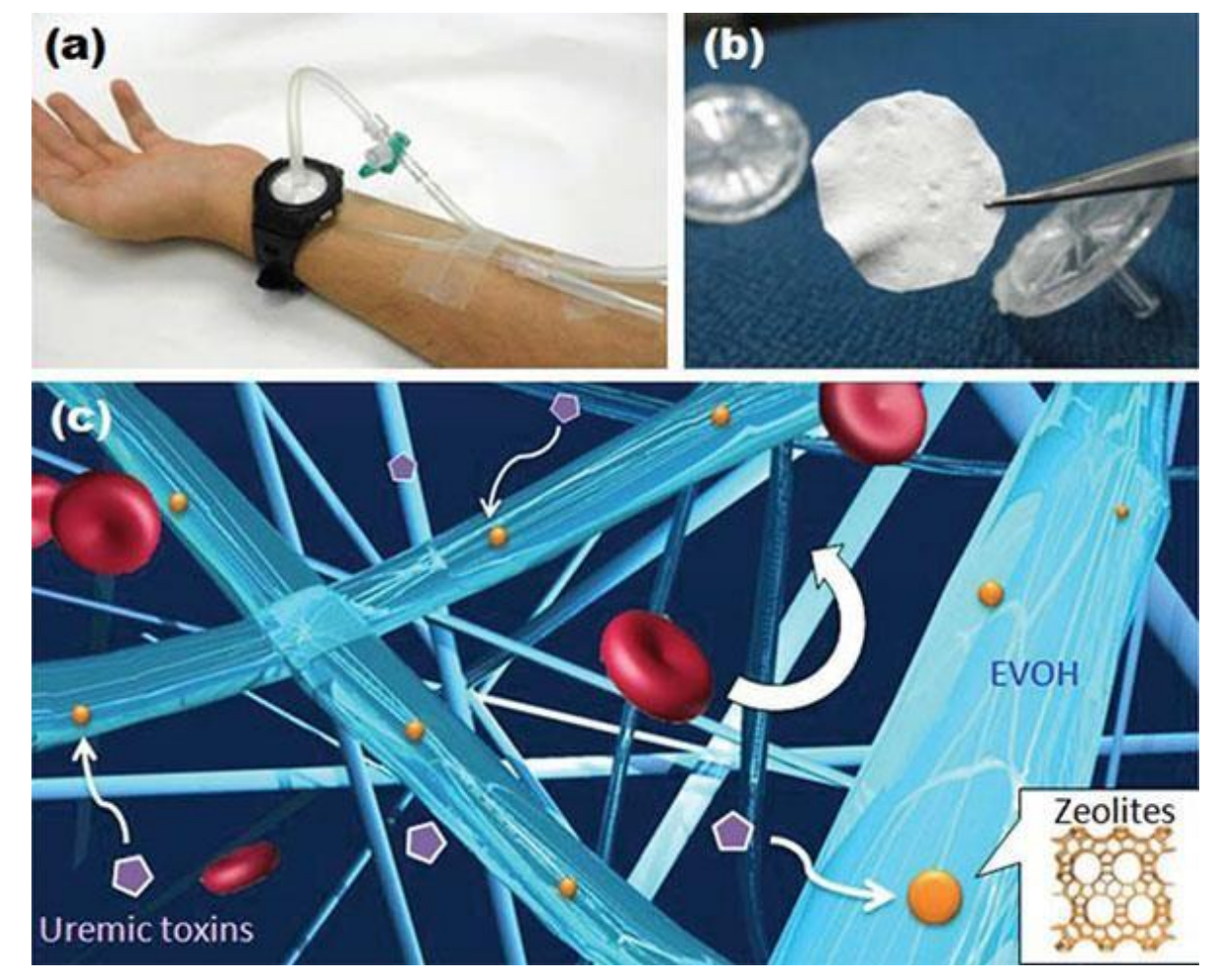

Figure 15. Nanofiber mesh filters blood of toxins allows for tiny hemodialysis machines: (a) Photographs of a wearable blood purification system; (b) zeolite-polymer composite nanofiber mesh; (c) Nanofiber is composed of blood compatible poly(ethylene-co-vinyl alcohol) as the primary matrix polymer and zeolites which are capable of selectively adsorbing uremic toxins (x). Copyright 2014, Royal Society of Chemistry.

\section{Concluding Remark}

Nanofibers are important and versatile class of nanomaterials that are attracting increasing attention from academics as well as several industries in recent years. Electrospun nanofibers have 
providing high surface areas, flexibility, high interconnected porosity, surface functionality for enzyme immobilization as sensing elements and electrochemical transduction of biosensors. The nanofiber membranes can be used in ultrahigh air filtration, wastewater treatment, water purification, and blood filtration with high efficiency at low pressure. Nanofibers have received a great deal of attention in development of new generation of drug delivery system due to the unique features including high drug loading, encapsulation efficiency, enhanced therapeutic index, localized delivery, reduced drug side effects, ability to modulate drug release. Although some successful and available examples of nanofibers-based products for biomedical nanofibrous materials these have not yet been fully explored in biomedical and healthcare fields, this sector is still being required more attempts to achieve the most ideal nanofiber as a tissue engineered scaffolds, wound dressing for effective biomedical applications in vivo in the large scale in market. Nanofibers have shown the most promising results as dressings for wound healing and tissue engineered scaffolds with architectures and functions similar to these of native extracellular matrix. The nanofibrous scaffolds are currently being used in vasculature, skin, bone, cartilage, neural and tendon/ligament.

\section{References}

1. S. Akbarian, J. Sojoodi, F. Monnavari, H. Heidari, P. Khosravian, H. A Javar, A. Assadi, R. Rasouli, M. Saffari and S. AS Shandiz, Letters in Drug Design \& Discovery, 2017, 14, 827-836.

2. N. Hashempour Alamdari, M. Alaei-Beirami, S. Shandiz, S. Ataollah, H. Hejazinia, R. Rasouli, M. Saffari, S. E. Sadat Ebrahimi, A. Assadi and M. Shafiee Ardestani, Contrast media \& molecular imaging, 2017, 2017.

3. A. Kebriaezadeh, S. Ashrafi, R. Rasouli, S. E. S. Ebrahimi, M. P. Hamedani, A. Assadi, M. Saffari and M. S. Ardestani, Advances in nano research, 2016, 4, 145-156.

4. S. H. EBRAHIMI, R. RASOULI, S. E. ALAVI, A. AKBARZADEH and M. E. M. KOOHI, 2015.

5. R. RASOULI, Z. HOSSEINIAN, A. AZARNOOSH, M. MORTAZAVI and A. AKBARZADEH, 2015.

6. A. K. Sharma, R. K. Keservani and R. K. Kesharwani, Nanobiomaterials: Applications in Drug Delivery, CRC Press, 2018.

7. A. Keshavarz, S. Hajbabaei, J. Sojoodi, M. Saffari, M. A. A. Afshar, F. Monnavari, E. M. Pargoo, R. Rasouli, H. Hejazinia and A. Assadi.

8. R. Rasouli, M. Saffari, S. E. S. Ebrahimi, A. Asaadi and M. Shafiee.

9. P. N. Sudha, K. Sangeetha, K. Vijayalakshmi and A. Barhoum, in Emerging Applications of Nanoparticles and Architecture Nanostructures, Elsevier, 2018, pp. 341-384.

10. A. Barhoum and M. L. García-Betancourt, in Emerging Applications of Nanoparticles and Architecture Nanostructures, Elsevier, 2018, pp. 279-304. 
11. S. Prasad, V. Kumar, S. Kirubanandam and A. Barhoum, in Emerging Applications of Nanoparticles and Architecture Nanostructures, Elsevier, 2018, pp. 305-340.

12. K. X. Tan, A. Barhoum, S. Pan and M. K. Danquah, in Emerging Applications of Nanoparticles and Architecture Nanostructures, Elsevier, 2018, pp. 121-139.

13. N. Bhardwaj and S. C. Kundu, Biotechnology advances, 2010, 28, 325-347.

14. A. O. Turky, A. Barhoum, M. MohamedRashad and M. Bechlany, Journal of Materials Science: Materials in Electronics, 2017, 28, 17526-17532.

15. K. Feng, H. Sun, M. A. Bradley, E. J. Dupler, W. V. Giannobile and P. X. Ma, Journal of controlled release, 2010, 146, 363-369.

16. J. Xue, M. He, H. Liu, Y. Niu, A. Crawford, P. D. Coates, D. Chen, R. Shi and L. Zhang, Biomaterials, 2014, 35, 9395-9405.

17. S. Çalamak, C. Erdoğdu, M. Özalp and K. Ulubayram, Materials Science and Engineering: C, 2014, 43, 11-20.

18. J. Wu, Y. Zheng, W. Song, J. Luan, X. Wen, Z. Wu, X. Chen, Q. Wang and S. Guo, Carbohydrate polymers, 2014, 102, 762-771.

19. S. E. Gilchrist, D. Lange, K. Letchford, H. Bach, L. Fazli and H. M. Burt, Journal of controlled release, 2013, 170, 64-73.

20. K. J. Cash and H. A. Clark, Trends in molecular medicine, 2010, 16, 584-593.

21. K. Manesh, P. Santhosh, A. Gopalan and K.-P. Lee, Analytical Biochemistry, 2007, 360, 189-195.

22. T. J. Sill and H. A. von Recum, Biomaterials, 2008, 29, 1989-2006.

23. X. Hu, S. Liu, G. Zhou, Y. Huang, Z. Xie and X. Jing, Journal of controlled release, 2014, 185, 1221.

24. G. Liu, J. Ding, L. Qiao, A. Guo, B. P. Dymov, J. T. Gleeson, T. Hashimoto and K. Saijo, Chemistry-A European Journal, 1999, 5, 2740-2749.

25. G. M. Whitesides and B. Grzybowski, Science, 2002, 295, 2418-2421.

26. C. R. Martin, Chemistry of Materials, 1996, 8, 1739-1746.

27. L. Feng, S. Li, H. Li, J. Zhai, Y. Song, L. Jiang and D. Zhu, Angewandte Chemie, 2002, 114, 12691271.

28. P. X. Ma and R. Zhang, 1999.

29. T. Ondarcuhu and C. Joachim, EPL (Europhysics Letters), 1998, 42, 215.

30. J. Deitzel, J. Kleinmeyer, J. Hirvonen and N. B. Tan, Polymer, 2001, 42, 8163-8170.

31. H. Fong and D. H. Reneker, Electrospinning and the formation of nanofibers, chapter, 2001.

32. E.-R. Kenawy, G. L. Bowlin, K. Mansfield, J. Layman, D. G. Simpson, E. H. Sanders and G. E. Wnek, Journal of controlled release, 2002, 81, 57-64.

33. A. Aluigi, A. Varesano, A. Montarsolo, C. Vineis, F. Ferrero, G. Mazzuchetti and C. Tonin, Journal of Applied Polymer Science, 2007, 104, 863-870.

34. H. Jiang, Y. Hu, Y. Li, P. Zhao, K. Zhu and W. Chen, Journal of controlled release, 2005, 108, $237-$ 243.

35. S. Y. Chew, J. Wen, E. K. Yim and K. W. Leong, Biomacromolecules, 2005, 6, 2017-2024.

36. T. G. Kim, D. S. Lee and T. G. Park, International journal of pharmaceutics, 2007, 338, 276-283.

37. A. G. Kanani and S. H. Bahrami, Trends Biomater Artif Organs, 2010, 24, 93-115.

38. A. Greiner and J. H. Wendorff, Angewandte Chemie International Edition, 2007, 46, 5670-5703.

39. E. T. Vargas, N. do Vale Baracho, J. De Brito and A. De Queiroz, Acta biomaterialia, 2010, 6, 10691078.

40. M. S. Khil, D. I. Cha, H. Y. Kim, I. S. Kim and N. Bhattarai, Journal of Biomedical Materials Research Part B: Applied Biomaterials, 2003, 67, 675-679.

41. T. Elsdale and J. Bard, The Journal of cell biology, 1972, 54, 626-637.

42. L. Weng and J. Xie, Current pharmaceutical design, 2015, 21, 1944-1959.

43. W. Cui, Y. Zhou and J. Chang, Science and Technology of Advanced Materials, 2010, 11, 014108.

44. G. Khang, S. J. Lee, M. S. Kim and H. B. Lee, Encyclopedia of Medical devices and instrumentation, 2006.

45. T. S. Bentley and S. G. Hanson, Milliman Research Report: Milliman, 2014.

46. R. Langer, Pharmaceutical research, 1997, 14, 840.

47. H. Pereira, A. M. Frias, J. M. Oliveira, J. Espregueira-Mendes and R. L. Reis, Arthroscopy: The Journal of Arthroscopic \& Related Surgery, 2011, 27, 1706-1719.

48. X. Wang, B. Ding and B. Li, Materials Today, 2013, 16, 229-241.

49. C. Xu, R. Inai, M. Kotaki and S. Ramakrishna, Biomaterials, 2004, 25, 877-886. 
50.

51.

52.

53.

54.

55.

56.

57.

58.

59.

60.

61.

62.

63.

64.

65.

66.

67.

68.

69.

70.

71.

72.

73.

74.

75.

76.

77.

78.

79.

80.

81.

82.

83.

84.

85.

86.

87.

88.

W. He, T. Yong, W. E. Teo, Z. Ma and S. Ramakrishna, Tissue engineering, 2005, 11, 1574-1588. Z. Ma, M. Kotaki, T. Yong, W. He and S. Ramakrishna, Biomaterials, 2005, 26, 2527-2536.

C. Vaz, S. Van Tuijl, C. Bouten and F. Baaijens, Acta biomaterialia, 2005, 1, 575-582.

R. Y. Basha, T. Sampath Kumar and M. Doble, Macromolecular Materials and Engineering, 2017, 302.

C. Zhu, C. Wang, R. Chen and C. Ru, in EMBEC \& NBC 2017, Springer, 2017, pp. 1-4.

H. Yoshimoto, Y. Shin, H. Terai and J. Vacanti, Biomaterials, 2003, 24, 2077-2082.

C. Li, C. Vepari, H.-J. Jin, H. J. Kim and D. L. Kaplan, Biomaterials, 2006, 27, 3115-3124.

M. Shin, H. Yoshimoto and J. P. Vacanti, Tissue engineering, 2004, 10, 33-41.

W. Cui, X. Li, S. Zhou and J. Weng, Journal of Biomedical Materials Research Part A, 2007, 82, 831-841.

C. Burger and B. Chu, Colloids and Surfaces B: Biointerfaces, 2007, 56, 134-141.

W.-J. Li, R. Tuli, C. Okafor, A. Derfoul, K. G. Danielson, D. J. Hall and R. S. Tuan, Biomaterials, 2005, 26, 599-609.

J.-P. Chen and C.-H. Su, Acta biomaterialia, 2011, 7, 234-243.

F. Yang, R. Murugan, S. Wang and S. Ramakrishna, Biomaterials, 2005, 26, 2603-2610.

L. Ghasemi-Mobarakeh, M. P. Prabhakaran, M. Morshed, M.-H. Nasr-Esfahani and S. Ramakrishna, Biomaterials, 2008, 29, 4532-4539.

S. Sahoo, S. L. Toh and J. C. Goh, Biomaterials, 2010, 31, 2990-2998.

S. Sahoo, L.-T. Ang, J. C.-H. Goh and S.-L. Toh, Differentiation, 2010, 79, 102-110.

J. G. Barber, A. M. Handorf, T. J. Allee and W.-J. Li, Tissue Engineering Part A, 2011, 19, 1265 1274.

J. Baier Leach, K. A. Bivens, C. W. Patrick Jr and C. E. Schmidt, Biotechnology and bioengineering, 2003, 82, 578-589.

J. Stitzel, J. Liu, S. J. Lee, M. Komura, J. Berry, S. Soker, G. Lim, M. Van Dyke, R. Czerw and J. J. Yoo, Biomaterials, 2006, 27, 1088-1094.

K. S. Rho, L. Jeong, G. Lee, B.-M. Seo, Y. J. Park, S.-D. Hong, S. Roh, J. J. Cho, W. H. Park and B.-M. Min, Biomaterials, 2006, 27, 1452-1461.

W. J. Li, K. G. Danielson, P. G. Alexander and R. S. Tuan, Journal of Biomedical Materials

Research Part A, 2003, 67, 1105-1114.

P. Wutticharoenmongkol, N. Sanchavanakit, P. Pavasant and P. Supaphol, Macromolecular bioscience, 2006, 6, 70-77.

H. J. Shin, C. H. Lee, I. H. Cho, Y.-J. Kim, Y.-J. Lee, I. A. Kim, K.-D. Park, N. Yui and J.-W. Shin, Journal of Biomaterials Science, Polymer Edition, 2006, 17, 103-119.

X. Liu, J. M. Holzwarth and P. X. Ma, Macromolecular bioscience, 2012, 12, 911-919.

S. Agarwal, J. H. Wendorff and A. Greiner, Polymer, 2008, 49, 5603-5621.

S. Y. Chew, R. Mi, A. Hoke and K. W. Leong, Biomaterials, 2008, 29, 653-661.

M. C. McManus, S. A. Sell, W. C. Bowen, H. P. Koo, D. G. Simpson and G. L. Bowlin, Journal of Engineered Fabrics \& Fibers (JEFF), 2008, 3.

X. Zhang, C. B. Baughman and D. L. Kaplan, Biomaterials, 2008, 29, 2217-2227.

S.-Y. Shin, H.-N. Park, K.-H. Kim, M.-H. Lee, Y. S. Choi, Y.-J. Park, Y.-M. Lee, Y. Ku, I.-C. Rhyu and S.-B. Han, Journal of periodontology, 2005, 76, 1778-1784.

P. Kuppan, K. S. Vasanthan, D. Sundaramurthi, U. M. Krishnan and S. Sethuraman, Biomacromolecules, 2011, 12, 3156-3165.

Y. Itani, S. Asamura, M. Matsui, Y. Tabata and N. Isogai, Plastic and reconstructive surgery, 2014, 133, 805e-813e.

X. T. Wen, H. S. Fan, Y. F. Tan, H. Cao, H. Li, B. Cai and X. D. Zhang, 2005.

S. J. Lee, J. J. Yoo, G. J. Lim, A. Atala and J. Stitzel, Journal of Biomedical Materials Research Part A, 2007, 83, 999-1008.

C. H. Lee, H. J. Shin, I. H. Cho, Y.-M. Kang, I. A. Kim, K.-D. Park and J.-W. Shin, Biomaterials, 2005, 26, 1261-1270.

W. K. Son, J. H. Youk and W. H. Park, Biomacromolecules, 2004, 5, 197-201.

B.-M. Min, Y. You, J.-M. Kim, S. J. Lee and W. H. Park, Carbohydrate Polymers, 2004, 57, 285292.

H. Pan, H. Jiang and W. Chen, Biomaterials, 2006, 27, 3209-3220.

Z. Ma, W. He, T. Yong and S. Ramakrishna, Tissue engineering, 2005, 11, 1149-1158.

W. He, Z. Ma, T. Yong, W. E. Teo and S. Ramakrishna, Biomaterials, 2005, 26, 7606-7615. 
89. H. Zhou and J. Lee, Acta biomaterialia, 2011, 7, 2769-2781.

90. B. Dhandayuthapani, Y. Yoshida, T. Maekawa and D. S. Kumar, International Journal of Polymer Science, 2011, 2011.

91. A. Hasan, A. Memic, N. Annabi, M. Hossain, A. Paul, M. R. Dokmeci, F. Dehghani and A. Khademhosseini, Acta biomaterialia, 2014, 10, 11-25.

92. Y. M. Ju, J. San Choi, A. Atala, J. J. Yoo and S. J. Lee, Biomaterials, 2010, 31, 4313-4321.

93. Y.-C. Jiang, L. Jiang, A. Huang, X.-F. Wang, Q. Li and L.-S. Turng, Materials Science and Engineering: C, 2017, 71, 901-908.

94. H.-F. Guo, W.-W. Dai, D.-H. Qian, Z.-X. Qin, Y. Lei, X.-Y. Hou and C. Wen, Acta biomaterialia, 2017, 54, 107-116.

95. Y. Zhang, J. R. Venugopal, A. El-Turki, S. Ramakrishna, B. Su and C. T. Lim, Biomaterials, 2008, 29, 4314-4322.

96. J. R. Venugopal, S. Low, A. T. Choon, A. B. Kumar and S. Ramakrishna, Artificial organs, 2008, 32, 388-397.

97. S. Wu, B. Duan, X. Qin and J. T. Butcher, Acta biomaterialia, 2017, 51, 89-100.

98. E. G. Fernandes, V. Zucolotto and A. A. De Queiroz, Journal of Macromolecular Science, Part A: Pure and Applied Chemistry, 2010, 47, 1203-1207.

99. V. Bhaarathy, J. Venugopal, C. Gandhimathi, N. Ponpandian, D. Mangalaraj and S. Ramakrishna, Materials Science and Engineering: C, 2014, 44, 268-277.

100. J. Yu, A.-R. Lee, W.-H. Lin, C.-W. Lin, Y.-K. Wu and W.-B. Tsai, Tissue Engineering Part A, 2014, 20, 1896-1907.

101. P.-H. Chen, H.-C. Liao, S.-H. Hsu, R.-S. Chen, M.-C. Wu, Y.-F. Yang, C.-C. Wu, M.-H. Chen and W.-F. Su, RSC Advances, 2015, 5, 6932-6939.

102. Y. Liu, X. Liang, S. Wang and K. Hu, Journal of Biomaterials and Tissue Engineering, 2016, 6, 719728.

103. A. Shafiee, M. Soleimani, G. A. Chamheidari, E. Seyedjafari, M. Dodel, A. Atashi and Y. Gheisari, Journal of Biomedical Materials Research Part A, 2011, 99, 467-478.

104. J. K. Wise, A. L. Yarin, C. M. Megaridis and M. Cho, Tissue Engineering Part A, 2008, 15, $913-$ 921.

105. Z. Lin, W. Gao, L. Ma, H. Xia, W. Xie, Y. Zhang and X. Chen, Journal of Bioactive and Compatible Polymers, 2017, 0883911517715659.

106. Z. Zarekhalili, S. H. Bahrami, M. Ranjbar-Mohammadi and P. B. Milan, International journal of biological macromolecules, 2017, 94, 679-690.

107. W. Cui, X. Zhu, Y. Yang, X. Li and Y. Jin, Materials Science and Engineering: C, 2009, 29, 18691876.

108. S. G. Kumbar, S. P. Nukavarapu, R. James, L. S. Nair and C. T. Laurencin, Biomaterials, 2008, 29, 4100-4107.

109. S. Gomes, G. Rodrigues, G. Martins, C. Henriques and J. C. Silva, International journal of biological macromolecules, 2017, 102, 1174-1185.

110. W. Jia, L. Su and Y. Lei, Biosensors and Bioelectronics, 2011, 30, 158-164.

111. Y. J. Shin and J. Kameoka, Journal of Industrial and Engineering Chemistry, 2012, 18, 193-197.

112. Z.-G. Wang, L.-S. Wan, Z.-M. Liu, X.-J. Huang and Z.-K. Xu, Journal of Molecular Catalysis B: Enzymatic, 2009, 56, 189-195.

113. K. Mondal, M. A. Ali, V. V. Agrawal, B. D. Malhotra and A. Sharma, ACS applied materials \& interfaces, 2014, 6, 2516-2527.

114. B. Ding, M. Wang, X. Wang, J. Yu and G. Sun, Materials Today, 2010, 13, 16-27.

115. A. K. Wanekaya, W. Chen, N. V. Myung and A. Mulchandani, Electroanalysis, 2006, 18, 533-550.

116. D. N. Tran and K. J. Balkus, Topics in Catalysis, 2012, 55, 1057-1069.

117. A. Sassolas, L. J. Blum and B. D. Leca-Bouvier, Analyst, 2011, 136, 257-274.

118. J. Wang, Biosensors and Bioelectronics, 2006, 21, 1887-1892.

119. Y. Luo, S. Nartker, H. Miller, D. Hochhalter, M. Wiederoder, S. Wiederoder, E. Setterington, L. T. Drzal and E. C. Alocilja, Biosensors and Bioelectronics, 2010, 26, 1612-1617.

120. Y. Luo, S. Nartker, M. Wiederoder, H. Miller, D. Hochhalter, L. T. Drzal and E. C. Alocilja, IEEE transactions on nanotechnology, 2012, 11, 676-681.

121. K. B. Paul, S. Kumar, S. Tripathy, S. R. K. Vanjari, V. Singh and S. G. Singh, Biosensors and Bioelectronics, 2016, 80, 39-46.

122. E. Eksin and A. Erdem, Electroanalysis, 2016. 
123. H. Zhang, Q. Zhao, X.-F. Li and X. C. Le, Analyst, 2007, 132, 724-737.

124. X. Wang, G. Shu, C. Gao, Y. Yang, Q. Xu and M. Tang, Analytical Biochemistry, 2014, 466, 51-58.

125. N.-H. Kim, S.-J. Choi, D.-J. Yang, J. Bae, J. Park and I.-D. Kim, Sensors and Actuators B: Chemical, 2014, 193, 574-581.

126. M.-S. Choi and Y.-J. Kim, European Polymer Journal, 2012, 48, 1988-1996.

127. M. A. Ali, K. Mondal, C. Singh, B. D. Malhotra and A. Sharma, Nanoscale, 2015, 7, 7234-7245.

128. L. Z. Swisher, A. M. Prior, M. J. Gunaratna, S. Shishido, F. Madiyar, T. A. Nguyen, D. H. Hua and J. Li, Nanomedicine: Nanotechnology, Biology and Medicine, 2015, 11, 1695-1704.

129. N. Zhang, Y. Deng, Q. Tai, B. Cheng, L. Zhao, Q. Shen, R. He, L. Hong, W. Liu and S. Guo, Advanced materials, 2012, 24, 2756-2760.

130. B. Rezaei, M. Ghani, A. M. Shoushtari and M. Rabiee, Biosensors and Bioelectronics, 2016, 78, 513-523.

131. S. C. Sundararaj, M. V. Thomas, R. Peyyala, T. D. Dziubla and D. A. Puleo, Biomaterials, 2013, 34, 8835-8842.

132. R. Vasita and D. S. Katti, International journal of nanomedicine, 2006, 1, 15.

133. P. F. McDonald, J. G. Lyons, L. M. Geever and C. L. Higginbotham, Journal of materials science, 2010, 45, 1284-1292.

134. E. Piskin, N. Bölgen, S. Egri and I. A. Isoglu, 2007.

135. C. He, W. Nie and W. Feng, Journal of Materials Chemistry B, 2014, 2, 7828-7848.

136. W. Xu, W. Yang and Y. Yang, Biotechnology progress, 2009, 25, 1788-1795.

137. H. S. Yoo, T. G. Kim and T. G. Park, Advanced drug delivery reviews, 2009, 61, 1033-1042.

138. D. W. Chen, Y.-H. Hsu, J.-Y. Liao, S.-J. Liu, J.-K. Chen and S. W.-N. Ueng, International journal of pharmaceutics, 2012, 430, 335-341.

139. X. Zong, K. Kim, D. Fang, S. Ran, B. S. Hsiao and B. Chu, Polymer, 2002, 43, 4403-4412.

140. Y. Zhang, C. T. Lim, S. Ramakrishna and Z.-M. Huang, Journal of Materials Science: Materials in Medicine, 2005, 16, 933-946.

141. J. Sharma, M. Lizu, M. Stewart, K. Zygula, Y. Lu, R. Chauhan, X. Yan, Z. Guo, E. K. Wujcik and S. Wei, Polymers, 2015, 7, 186-219.

142. A. Khalf and S. V. Madihally, European Journal of Pharmaceutics and Biopharmaceutics, 2017, 112, $1-17$.

143. Z. Zhang, J. Tang, H. Wang, Q. Xia, S. Xu and C. C. Han, ACS applied materials \& interfaces, 2015, 7, 26400-26404.

144. A. F. De Faria, F. o. Perreault, E. Shaulsky, L. H. Arias Chavez and M. Elimelech, ACS applied materials \& interfaces, 2015, 7, 12751-12759.

145. K. A. Rieger and J. D. Schiffman, Carbohydrate polymers, 2014, 113, 561-568.

146. K. Kalwar, W.-X. Sun, D.-L. Li, X.-J. Zhang and D. Shan, Reactive and Functional Polymers, 2016, 107, 87-92.

147. L. Zhang, J. Huang, T. Si and R. X. Xu, Expert review of medical devices, 2012, 9, 595-612.

148. Y. Jing, Y. Zhu, X. Yang, J. Shen and C. Li, Langmuir, 2010, 27, 1175-1180.

149. J. H. Park, S. M. Park, I. J. Kwon, J. M. Hyun, Y. Deng, Y. G. Jeong, I. W. Cheong and J. H. Yeum, Journal of Composite Materials, 2013, 47, 3367-3378.

$150 . \quad$ D.-G. Yu, X.-X. Shen, C. Branford-White, K. White, L.-M. Zhu and S. A. Bligh, Nanotechnology, 2009, 20, 055104.

151. F. Ignatious, L. Sun, C.-P. Lee and J. Baldoni, Pharmaceutical research, 2010, 27, 576-588.

152. J. Bhandari, H. Mishra, P. K. Mishra, R. Wimmer, F. J. Ahmad and S. Talegaonkar, International journal of nanomedicine, 2017, 12, 2021.

153. K. E. Knockenhauer, K. M. Sawicka, E. J. Roemer and S. R. Simon, 2008.

154. T. Ngawhirunpat, P. Opanasopit, T. Rojanarata, P. Akkaramongkolporn, U. Ruktanonchai and P. Supaphol, Pharmaceutical development and technology, 2009, 14, 73-82.

155. J. Yun, J. S. Im, Y.-S. Lee and H.-I. Kim, European Polymer Journal, 2011, 47, 1893-1902.

156. L. Wang, M. Wang, P. D. Topham and Y. Huang, RSC Advances, 2012, 2, 2433-2438.

157. A. K. Blakney, C. Ball, E. A. Krogstad and K. A. Woodrow, Antiviral research, 2013, 100, S9-S16.

158. O. S. Manoukian, R. Matta, J. Letendre, P. Collins, A. D. Mazzocca and S. G. Kumbar, Biomedical Nanotechnology: Methods and Protocols, 2017, 261-278.

159. H. Chen and Y. L. Hsieh, Journal of Polymer Science Part A: Polymer Chemistry, 2004, 42, 63316339.

160. W. K. Son, J. H. Youk and W. H. Park, Carbohydrate polymers, 2006, 65, 430-434. 
161. A. M. Abdelgawad, S. M. Hudson and O. J. Rojas, Carbohydrate polymers, 2014, 100, 166-178.

162. T. Okuda, K. Tominaga and S. Kidoaki, Journal of controlled release, 2010, 143, 258-264.

163. W. Cui, X. Li, X. Zhu, G. Yu, S. Zhou and J. Weng, Biomacromolecules, 2006, 7, 1623-1629.

164. G. Buschle-Diller, J. Cooper, Z. Xie, Y. Wu, J. Waldrup and X. Ren, Cellulose, 2007, 14, 553-562.

165. S. Tungprapa, I. Jangchud and P. Supaphol, Polymer, 2007, 48, 5030-5041.

166. Z. Xie and G. Buschle-Diller, Journal of Applied Polymer Science, 2010, 115, 1-8.

167. M. Zamani, M. Morshed, J. Varshosaz and M. Jannesari, European Journal of Pharmaceutics and Biopharmaceutics, 2010, 75, 179-185.

168. Q. Wei, Functional nanofibers and their applications, Elsevier, 2012.

169. S. P. Parwe, P. N. Chaudhari, K. K. Mohite, B. S. Selukar, S. S. Nande and B. Garnaik, International journal of nanomedicine, 2014, 9, 1463.

170. R. Qi, R. Guo, F. Zheng, H. Liu, J. Yu and X. Shi, Colloids and Surfaces B: Biointerfaces, 2013, 110, $148-155$.

171. T. Khampieng, G. E. Wnek and P. Supaphol, Journal of Biomaterials Science, Polymer Edition, 2014, 25, 1292-1305.

172. H. Yang, P. F. Gao, W. B. Wu, X. X. Yang, Q. L. Zeng, C. Li and C. Z. Huang, Polymer Chemistry, 2014, 5, 1965-1975.

173. S. Wang, F. Zheng, Y. Huang, Y. Fang, M. Shen, M. Zhu and X. Shi, ACS applied materials \& interfaces, 2012, 4, 6393-6401.

174. S. S. Kim and J. Lee, Carbohydrate polymers, 2014, 102, 231-237.

175. J. Song, H. Kang, C. Lee, S. H. Hwang and J. Jang, ACS applied materials \& interfaces, 2011, 4, 460-465.

176. T. T. T. Nguyen, B. Tae and J. S. Park, Journal of materials science, 2011, 46, 6528-6537.

177. G. N. Sichani, M. Morshed, M. Amirnasr and D. Abedi, Journal of Applied Polymer Science, 2010, 116, 1021-1029.

178. J. Yuan, J. Geng, Z. Xing, J. Shen, I. K. Kang and H. Byun, Journal of Applied Polymer Science, 2010, 116, 668-672.

179. H. Kong and J. Jang, Langmuir, 2008, 24, 2051-2056.

180. P. Koushki, S. H. Bahrami and M. Ranjbar-Mohammadi, Journal of Industrial Textiles, 2017, 1528083716674906.

181. F. Zheng, S. Wang, S. Wen, M. Shen, M. Zhu and X. Shi, Biomaterials, 2013, 34, 1402-1412.

182. Z. Aytac, S. Y. Dogan, T. Tekinay and T. Uyar, Colloids and Surfaces B: Biointerfaces, 2014, 120, 125-131.

183. N. Monteiro, M. Martins, A. Martins, N. A. Fonseca, J. N. Moreira, R. L. Reis and N. M. Neves, Acta biomaterialia, 2015, 18, 196-205.

184. R. F. Bonan, P. R. Bonan, A. U. Batista, F. C. Sampaio, A. J. Albuquerque, M. C. Moraes, L. H. Mattoso, G. M. Glenn, E. S. Medeiros and J. E. Oliveira, Materials Science and Engineering: C, 2015, 48, 372-377.

185. J.-A. Park and S.-B. Kim, Reactive and Functional Polymers, 2015, 93, 30-37.

186. C. Huang, S. J. Soenen, E. van Gulck, G. Vanham, J. Rejman, S. Van Calenbergh, C. Vervaet, T. Coenye, H. Verstraelen and M. Temmerman, Biomaterials, 2012, 33, 962-969.

187. T. N. Grooms, H. R. Vuong, K. M. Tyo, D. A. Malik, L. B. Sims, C. P. Whittington, K. E. Palmer, N. Matoba and J. M. Steinbach-Rankins, Antimicrobial Agents and Chemotherapy, 2016, 60, 65186531.

188. S. E. Aniagyei, L. B. Sims, D. A. Malik, K. M. Tyo, K. C. Curry, W. Kim, D. A. Hodge, J. Duan and J. M. Steinbach-Rankins, Materials Science and Engineering: C, 2017, 72, 238-251.

189. E. A. Krogstad and K. A. Woodrow, International journal of pharmaceutics, 2014, 475, 282-291.

190. V. A. d. SANTOS, P. V. A. VIERA, A. M. d. OLIVEIRA, M. H. A. ZANIN and M. A. Borsatti, Brazilian oral research, 2014, 28, 1-6.

191. S. Harini, M. Venkatesh, S. Radhakrishnan, M. H. U. T. Fazil, E. T. L. Goh, S. Rui, C. Dhand, S. T. Ong, V. A. Barathi and R. W. Beuerman, RSC Advances, 2016, 6, 41130-41141.

192. F. F. Veras, I. Roggia, P. Pranke, C. N. Pereira and A. Brandelli, European Journal of Pharmaceutical Sciences, 2016, 84, 70-76.

193. A. S. Mir, T. Garg, B. Vaidya, A. K. Goyal and G. Rath, Journal of Nanopharmaceutics and Drug Delivery, 2014, 2, 192-198.

194. F. A. Paskiabi, S. Bonakdar, M. A. Shokrgozar, M. Imani, Z. Jahanshiri, M. Shams-Ghahfarokhi and M. Razzaghi-Abyaneh, Materials Science and Engineering: C, 2017, 73, 130-136. 
195. V. Q. Nguyen, M. Ishihara, J. Kinoda, H. Hattori, S. Nakamura, T. Ono, Y. Miyahira and T. Matsui, Journal of nanobiotechnology, 2014, 12, 49.

196. P. Vashisth, K. Nikhil, S. C. Pemmaraju, P. A. Pruthi, V. Mallick, H. Singh, A. Patel, N. C. Mishra, R. P. Singh and V. Pruthi, Journal of Bioactive and Compatible Polymers, 2013, 28, 652-665.

197. P. A. Zapata, M. Larrea, L. Tamayo, F. M. Rabagliati, M. I. Azócar and M. Páez, Materials Science and Engineering: C, 2016, 69, 1282-1289.

198. D. M. du Plessis, M. Botes, L. M. T. Dicks and T. E. Cloete, Journal of Chemical Technology and Biotechnology, 2013, 88, 585-593.

199. C. H. Jang, Y. B. Cho, Y. S. Jang, M. S. Kim and G. H. Kim, International journal of pediatric otorhinolaryngology, 2015, 79, 1299-1305.

200. A. G. Ashbaugh, X. Jiang, J. Zheng, A. S. Tsai, W.-S. Kim, J. M. Thompson, R. J. Miller, J. H. Shahbazian, Y. Wang and C. A. Dillen, Proceedings of the National Academy of Sciences, 2016, 201613722.

201. J. J. Ahire, M. Hattingh, D. P. Neveling and L. M. Dicks, PloS one, 2016, 11, e0152755.

202. N. Bölgen, I. Vargel, P. Korkusuz, Y. Z. Menceloğlu and E. Pişkin, Journal of Biomedical Materials Research Part B: Applied Biomaterials, 2007, 81, 530-543.

203. J. S. Choi, K. W. Leong and H. S. Yoo, Biomaterials, 2008, 29, 587-596.

204. S. H. Park, T. G. Kim, H. C. Kim, D.-Y. Yang and T. G. Park, Acta biomaterialia, 2008, 4, 1198 1207.

205. L. Fan, H. Wang, K. Zhang, Z. Cai, C. He, X. Sheng and X. Mo, RSC Advances, 2012, 2, 41104119.

206. J. S. Choi, S. H. Choi and H. S. Yoo, Journal of Materials Chemistry, 2011, 21, 5258-5267.

207. S. Chen, B. Liu, M. A. Carlson, A. F. Gombart, D. A. Reilly and J. Xie, Nanomedicine, 2017.

208. H. M. Powell, D. M. Supp and S. T. Boyce, Biomaterials, 2008, 29, 834-843.

209. M. Ranjbar-Mohammadi, S. H. Bahrami and M. Joghataei, Materials Science and Engineering: C, 2013, 33, 4935-4943.

210. F. Gökmeşe, İ. Uslu and A. Aytimur, Polymer-Plastics Technology and Engineering, 2013, 52, 1259-1265.

211. A. Aytimur, S. Koçyiğit and İ. Uslu, Polymer-Plastics Technology and Engineering, 2013, 52, 661666.

212. A. Aytimur, S. Koçyiğit, İ. Uslu and F. Gökmeşe, International Journal of Polymeric Materials and Polymeric Biomaterials, 2015, 64, 111-116.

213. A. Aytimur and İ. Uslu, Polymer-Plastics Technology and Engineering, 2014, 53, 655-660.

214. P.-o. Rujitanaroj, N. Pimpha and P. Supaphol, Polymer, 2008, 49, 4723-4732.

215. N. Naseri, C. Algan, V. Jacobs, M. John, K. Oksman and A. P. Mathew, Carbohydrate Polymers, 2014, 109, 7-15.

216. A. J. Meinel, O. Germershaus, T. Luhmann, H. P. Merkle and L. Meinel, European Journal of Pharmaceutics and Biopharmaceutics, 2012, 81, 1-13.

217. J. J. Elsner and M. Zilberman, Acta biomaterialia, 2009, 5, 2872-2883.

218. M. Abrigo, S. L. McArthur and P. Kingshott, Macromolecular bioscience, 2014, 14, 772-792.

219. G. Thakral, J. LaFontaine, B. Najafi, T. K. Talal, P. Kim and L. A. Lavery, Diabetic foot \& ankle, 2013, 4, 22081.

220. B. Strauch, M. K. Patel, J. A. Navarro, M. Berdichevsky, H.-L. Yu and A. A. Pilla, Plastic and reconstructive surgery, 2007, 120, 425-430.

221. E. Timmenga, T. Andreassen, H. Houthoff and P. Klopper, British journal of plastic surgery, 1991, 44, 514-519.

222. K.-G. Malle, Scientific American, 1996, 274, 70-75.

223. , 2017.

224. H. Ozaki, 2004.

225. M. Servos, D. Bennie, B. Burnison, A. Jurkovic, R. McInnis, T. Neheli, A. Schnell, P. Seto, S. Smyth and T. Ternes, Science of the Total Environment, 2005, 336, 155-170.

226. M. Petrovic, A. Diaz, F. Ventura and D. Barceló, Environmental science \& technology, 2003, 37, $4442-4448$.

227. N. Vieno, T. Tuhkanen and L. Kronberg, Environmental Technology, 2006, 27, 183-192.

228. I. Suffet, J. Mallevialle and E. Kawczynski, Advances in taste-and-odor treatment and control, American Water Works Association, 1995.

229. M. Amin, A. Alazba and U. Manzoor, Advances in Materials Science and Engineering, 2014, 2014. 
230. K. Gopal, S. S. Tripathy, J. L. Bersillon and S. P. Dubey, Journal of hazardous materials, 2007, 140, $1-6$.

231. M. T. Amin, S. Ryu and H. Park, Journal of Water Supply: Research and Technology-Aqua, 2007, 56, 203-216.

232. C. Adams, Y. Wang, K. Loftin and M. Meyer, Journal of environmental engineering, 2002, 128, 253-260.

233. M. A. Shannon, P. W. Bohn, M. Elimelech, J. G. Georgiadis, B. J. Marinas and A. M. Mayes, Nature, 2008, 452, 301.

234. H. Strathmann, AIChE journal, 2001, 47, 1077-1087.

235. P. Jain and T. Pradeep, Biotechnology and bioengineering, 2005, 90, 59-63.

236. Y. Lv, H. Liu, Z. Wang, S. Liu, L. Hao, Y. Sang, D. Liu, J. Wang and R. Boughton, Journal of Membrane Science, 2009, 331, 50-56.

237. V. S. Sousa, C. Corniciuc and M. R. Teixeira, Water research, 2017, 109, 1-12.

238. S. L. Gora and S. A. Andrews, Chemosphere, 2017, 174, 363-370.

239. S. Baruah, S. K Pal and J. Dutta, Nanoscience \& Nanotechnology-Asia, 2012, 2, 90-102.

240. A. Sugunan, V. K. Guduru, A. Uheida, M. S. Toprak and M. Muhammed, Journal of the American Ceramic Society, 2010, 93, 3740-3744.

241. L. S. Zhong, J. S. Hu, H. P. Liang, A. M. Cao, W. G. Song and L. J. Wan, Advanced materials, 2006, 18, 2426-2431.

242. R. Crane and T. Scott, Journal of hazardous materials, 2012, 211, 112-125.

243. C. L. Mangun, Z. Yue, J. Economy, S. Maloney, P. Kemme and D. Cropek, Chemistry of Materials, 2001, 13, 2356-2360.

244. X. Zhao, L. Lv, B. Pan, W. Zhang, S. Zhang and Q. Zhang, Chemical engineering journal, 2011, 170, 381-394.

245. K. Yang, L. Zhu and B. Xing, Environmental science \& technology, 2006, 40, 1855-1861.

246. T. G. Hedderman, S. M. Keogh, G. Chambers and H. J. Byrne, The Journal of Physical Chemistry B, 2006, 110, 3895-3901.

247. S. Gotovac, C.-M. Yang, Y. Hattori, K. Takahashi, H. Kanoh and K. Kaneko, Journal of colloid and interface science, 2007, 314, 18-24.

248. M. S. Diallo, Journal, 2008.

249. A. Rether and M. Schuster, Reactive and Functional Polymers, 2003, 57, 13-21.

250. R. S. Barhate and S. Ramakrishna, Journal of Membrane Science, 2007, 296, 1-8.

251. L. Balogh, D. R. Swanson, D. A. Tomalia, G. L. Hagnauer and A. T. McManus, Nano letters, 2001, 1, 18-21.

252. Y. Chen, L. Wang, S. Jiang and H. Yu, Journal of Polymer Materials, 2003, 20, 279-284.

253. H. J. Jeon, J. S. Kim, T. G. Kim, J. H. Kim, W.-R. Yu and J. H. Youk, Applied Surface Science, 2008, 254, 5886-5890.

254. K. Lewis and A. M. Klibanov, TRENDS in Biotechnology, 2005, 23, 343-348.

255. A. Frenot and I. S. Chronakis, Current opinion in colloid \& interface science, 2003, 8, 64-75.

256. N. Singh, K. Mondal, M. Misra, A. Sharma and R. K. Gupta, RSC Advances, 2016, 6, 48109-48119.

257. A. Seaton, D. Godden, W. MacNee and K. Donaldson, The lancet, 1995, 345, 176-178.

258. S. A. A. N. Nasreen, S. Sundarrajan, S. A. S. Nizar, R. Balamurugan and S. Ramakrishna, Membranes, 2013, 3, 266-284.

259. Y. Zhang, S. Yuan, X. Feng, H. Li, J. Zhou and B. Wang, Journal of the American Chemical Society, 2016, 138, 5785-5788.

260. Q. Zhang, B. Damit, J. Welch, H. Park, C.-Y. Wu and W. Sigmund, Journal of Aerosol Science, 2010, 41, 880-888.

261. C.-J. Li, Y.-J. Li, J.-N. Wang and J. Cheng, Chemical engineering journal, 2013, 220, 294-301.

262. A. A. Taha, Y.-n. Wu, H. Wang and F. Li, Journal of environmental management, 2012, 112, 10-16.

263. S. Ramakrishna, K. Fujihara, W.-E. Teo, T. Yong, Z. Ma and R. Ramaseshan, Materials Today, 2006, 9, 40-50.

264. F. Yilmaz, G. Celep and G. Tetik, in Nanofiber Research-Reaching New Heights, InTech, 2016.

265. D. Smith, D. Reneker, W. Kataphinan and S. Dabney, PCT Int. Appl, 2001, 14.

266. C. Kim, Journal, 2013.

267. P. Taepaiboon, U. Rungsardthong and P. Supaphol, European Journal of Pharmaceutics and Biopharmaceutics, 2007, 67, 387-397. 
268. A. Fathi-Azarbayjani, L. Qun, Y. W. Chan and S. Y. Chan, Aaps Pharmscitech, 2010, 11, 11641170.

269. M. Faccini, C. Vaquero and D. Amantia, Journal of Nanomaterials, 2012, 2012, 18.

270. P. J. Rivero, A. Urrutia, J. Goicoechea and F. J. Arregui, Nanoscale research letters, 2015, 10, 501.

271. R. Agarwal Satya, S. Subramanian and R. Seeram, 2012.

272. N. Bedford and A. Steckl, ACS applied materials \& interfaces, 2010, 2, 2448-2455.

273. N. R. Dhineshbabu, G. Karunakaran, R. Suriyaprabha, P. Manivasakan and V. Rajendran, NanoMicro Letters, 2014, 6, 46-54. 